\title{
6. AZ ISKOLA SZÍNVONALA, EREDMÉNYESSÉGE, VONZEREJE
}

\author{
GARBACZNÉ OLASZ ANDREA - SZÜCSNÉ HÜTTER ESZTER
}

\section{Bevezetés}

A tanárképző intézmények gyakorlóiskolái mindig meghatározó modelljei a környezetükben lévő iskoláknak. Pedagógiai gyakorlatuk követendő mintaként szolgál, hivatkozási alap a többi intézmény számára. A gyakorlóiskolák vezetőtanárai a legeredményesebb, legszakszerűbb, a legújabb kutatási eredményeket tükröző modelleket kell hogy a gyakorlatukat teljesítő tanárképzős hallgatóknak megmutassák követendő példaként. A gyakorlóiskoláknak olyan tudásbázist kell felmutatniuk, amely képessé teszi őket arra, hogy szakmailag segítsék a többi intézményt, vagyis a tudásmegosztásra való képesség és szándék is meg kell hogy legyen pedagógusaikban. Kutatásunknak ebben a részében azt vizsgáltuk, hogy a gyakorlóiskola tevékenységében mennyire követhető nyomon az az igény, hogy a környék mintaiskolája legyen, vagyis hogy a hallgatók szakmai fejlődését támogató pedagógusok megfelelnek-e annak az elvárásnak, hogy a magas szintű szakmai tudás birtokában modellként szolgáljanak a hallgatók számára. A következő kérdésekre kerestük a választ: Mennyire rendelkezik a tantestület olyan pedagógiai-módszertani eszköztárral, amely a tanulók fejlődését nagymértékben előmozdítja (hozzáadott érték kérdése)? Milyen tényezők nehezítik, hogy a pedagógusok színvonalasabb nevelö-oktató munkát végezzenek? Mennyire nyitottak a pedagógusok arra, hogy tudásukat megosszák a kollégákkal? Milyen mértékű a szakmai együttműködés az egyetem és a gyakorlóiskola közt? Milyen szempontokat tartanak a szülők fontosnak az iskolaválasztásnál, és az elvárásaik milyen mértékben valósulnak meg?

A tanítási órákon használt eszközökről és módszerekről hogyan vélekednek a szülők, tanárok, tanulók? A tanárok miben látják a fejlődés akadályait? Milyen módszereket alkalmaznak?

A tanulók fejlődését minek tulajdonítják a szülők és a tanulók? Milyen az iskola megítélése?

Mennyire önreflektívek a pedagógusok? Milyen mértékű a pedagógusok motiváltsága? Mennyire elkötelezettek a pedagógusok az iskola oktató-nevelő munkája színvonalának a javítására? 


\section{Az iskola eredményessége}

Elöljáróban fontos leszögezni, hogy egy iskola vonzereje, külső megítélése nagymértékben függ az iskolában folyó pedagógiai munka színvonalától és eredményességétől.

Az iskolai eredményességi kutatások kezdetét Coleman (1966) egy vizsgálatához kötik, melynek célja a tanulói teljesítményekre gyakorolt iskolai hatás kimutatása volt. Az elmúlt körülbelül ötven év ilyen témájú kutatásait korszakolták a kutatási célok és az eredményességi fókuszok alapján. Az első korszakba Coleman és az ő követői tartoztak. A korszakok közül a negyedik kiemelendő, mert az eredményességi kutatások itt kapcsolódtak össze az iskolafejlesztéssel. Az iskolai hatások vizsgálata egyre részletesebb lett az évek során. Jelenleg a korszakolás ötödik szakaszában járunk. A leírások komplexebbé váltak. Ennek több oka is volt. Egyrészt a diszciplínák, úgymint a pszichológia, a szociológia, a vezetéstudomány stb. összekapcsolódtak. Egy másik ok az, hogy már nemcsak a közoktatást vizsgálják eredményességi szempontból, hanem a kisgyermekkori nevelést és a felsőoktatást is. Ezenkívül új mérési eszközök, statisztikai módszerek jelentek meg, amelyek sokkal pontosabb következtetésekre adtak lehetőséget. Ebben az ötödik korszakban egyre több rendszerező modellt állítottak fel a kutatók.

Teddlie és Reynolds (2000) kilenc iskolai eredményességet befolyásoló tényezőt határoztak meg 20 év kutatás után:

1. hatékony vezetés,

2. hatékony tanítás,

3. a tanulás támogatása,

4. pozitív iskolai kultúra,

5. megfelelően magas elvárások mindenki számára (tanárnak és tanulónak egyaránt),

6. a tanulói jogok és a felelősség hangsúlyozása,

7. a tanulók, az osztályok és az egész iskola (tehát minden szint) folyamatos monitorozása,

8. az iskola dolgozóinak szakmai fejlesztése,

9. a szülők bevonása.

Scheerens és munkatársai (2003) a következő eredményességi tényezőket említik:

1. magas elvárások (tanárnak és tanulónak egyaránt),

2. tanulásközpontú vezetés,

3. tanári együttműködés, kohézió és konszenzus a tantestületben,

4. az iskolai pedagógiai gyakorlat tartalmi és módszertani jellemzői (a tanterv minősége és prioritásai, a tanulás és tanítás kapcsán felmerülő tanulásszervezési kérdések, a tanítás során alkalmazott pedagógiai módszerek, a tanulók sajátos igényeinek figyelembevétele, a képességek szerinti differenciálás, a tanulási idő hatékony kihasználása, a tanulók 
értékelése, megerősítés és visszajelzés, lehetőség a tanulásra [pl. extrakurrikuláris foglalkozások], módszerek, tankönyvek, motiváció, az oktatási tartalom minősége),

5. az iskolai klíma jellemzői (az intézményen belüli kapcsolatok alakulása, a szervezeti kultúra sajátosságai, az intézményvezető vezetési stílusa),

6. az intézményi értékelés,

7. a szülők bevonása az iskola életébe, a szülőkkel fenntartott kapcsolatok kiterjedtsége, a tanárok és a szülők elégedettsége e kapcsolatokkal,

8. a tantermi klíma jellemzői (osztályon belüli kapcsolatok, a tanulással kapcsolatos attitűdök, a tanár-diák viszony alakulása),

9. a tanulási idő hatékony kihasználása,

10. differenciálás, megerősítés, visszajelzés.

A rendszerező kutatások az egyes tényezők hatásainak erősségeivel is foglalkoznak. Scheerenst és munkatársait érdekelte, hogy a felsorolt tényezők közül melyik hat a legerösebben az iskolai eredményességre. Miután feldolgoztak 155 tanulmányt, ami ezzel foglalkozott, számszerűsítették a hatások mértékét. Az eredmény alapján a tananyag minősége és a tanítási idő az, ami legerősebben hat. Ezt követi az iskolai klíma, a teljesítményorientáció és a szülők bevonása. Szerintük a legkevésbé a differenciálás, a tanári együttműködés és az iskolavezetés van kapcsolatban az eredményességgel.

Az eredményességi kutatások rámutatnak, hogy a tanulói teljesítményt elsősorban a családi háttér befolyásolja, és az iskolának csekély hatása van a tanulók teljesítményére. A magasabb státuszú családból származó gyerekek jobban teljesítenek, mint alacsonyabb státuszú társaik, a szülői háttér hatása tehát meghatározó marad a tanulók teljesítményében (Goldthorpe és Erikson, 2002). Kutatások sora vizsgálta ezt a kérdést, és azt, hogy miképpen lehet a kevésbé előnyös családi hátterü gyerekek iskolai teljesítményét növelni. A hétköznapi tapasztalatok alapján nyilvánvaló az, hogy kiemelkedő pedagógusok képesek ezeknél a gyerekeknél is számottevő eredményeket elérni. A 90-es évek ezt vizsgáló kutatásai már olyan eredményekről számolnak be, melyek szerint a tanulók teljesítményét a családi háttér mellett az iskolai hatások közül legerősebben a pedagógus munkájának minősége befolyásolja (Goldhaber, 2002). Van olyan amerikai kutatás, mely szerint a kiváló pedagógus másfélszer annyi teljesítményt képes kihozni a tanulókból, mint egy átlagos tanár, a nagyon rossz pedagógus pedig feleannyit (Hanushek, 1992). Mivel a pedagógusok hatékonysága ilyen módon előtérbe került, a kutatók azt is elkezdték vizsgálni, hogy vannak-e olyan mutatók, jelzőszámok, amelyek segítségével értékelhetők lennének a pedagógusi teljesítmények, és meg lehetne állapítani, hogy ki a hatékony, illetve kevésbé hatékony tanár. Az eredmények azt mutatták, hogy a pedagógusok teljesítményét nem lehet egyértelműen, egyszerű mutatókkal megbízhatóan 
mérni. Nem volt jelentős a kapcsolat a pedagógus tantárgyi tudása, képzettségi szintje (pl. a diplomája minősége), tanítási tapasztalatainak mennyisége és az általa tanított tanulók teljesítménye közt (Darling-Hammond, 2000). Ebből azonban nem szabad hamis következtetéseket levonnunk, és azt gondolni, hogy a tanár személyiségének „varázsa” a leginkább befolyásoló tényező a tanulók teljesítményére, és a fentebb felsoroltak nem számítanak. Ezek a kutatások azt bizonyítják, hogy a tanári hatékonyságot nem lehet csak standardizált eszközökkel, egyszerü mérőszámokkal mérni. A tanári hatékonyság komplexitásához ugyanis az is szorosan hozzátartozik, hogy a pedagógus mennyire tudja tanítási gyakorlatát hozzáigazítani az egyes tanulók, a különböző tanulói csoportok változó igényeihez. Megvan-e az a széles pedagógiai háttértudása, amely képessé teszi erre? Ha ez a háttértudása megvan, akkor megvan-e az a motiváltsága, hogy ezt a tudást használja a mindennapi gyakorlatban? Az indikátorokkal mérhető tudás tehát szükséges, de nem elégséges ahhoz, hogy a pedagógus hatékony legyen. Elmondhatjuk tehát, hogy a pedagógus munkájának nagy hatása lehet a tanulókra, és mérhető annak a valószínűsége, hogy egy iskolában a pedagógusok képesek-e hatékonyan tanítani. Az iskolavezetés felelőssége, hogy a pedagógusi kollektívában minél több olyan tanár dolgozzon, aki képes hatékonyan irányítani a tanítás-tanulás folyamatát. Felvetődik a kérdés, hogy milyen megoldásokat talál az iskolavezetés, amikor a nevelőtestületben dolgoznak gyenge hatékonysággal működő pedagógusok.

A 80-as évektől, a statisztikai módszerek fejlődésének következtében gyakoribbá váltak a „hozzáadott érték” vizsgálatán alapuló kutatások. Ezek szintén hasznos eszközök, amikor az iskolák eredményességét vizsgáljuk. Ennek kapcsán gyakran megfogalmazódik, hogy az általános tantervi célok és a kompetenciamérés fókusza között eltérés van, és összehangolásra volna szükség. Míg a kompetenciamérés a problémamegoldás és kreativitás vizsgálatát helyezi középpontba, addig a tanórák keretében sokszor történik adat- és tényszerü tudásátadás. Eltérés tapasztalható tehát a tantervi követelmények és a kompetenciamérés fókusza közt.

Annak ellenére, hogy a pedagógusok nagyrészt egyedül dolgoznak az osztályteremben, az iskola pedagógiai munkája kollektív teljesítmény is. Egy-egy pedagógus munkájának hatékonyságát az is meghatározza, hogy mennyire támogató az a szakmai közösség, amelyben tevékenykedik, és mennyire segíti őt az iskolavezetés. Az iskolai eredményességet vizsgáló kutatások az elmúlt időszakban kiterjedtek az iskolavezetés és a nevelőtestület szerepére is. Az eredmények szerint mindkettőnek jelentős hatása van a tanulói teljesítményekre (Leithwood és Riehl, 2003). A minőségi oktató-nevelő munkában a nevelőtestület és az intézményvezetés együtt dolgozik azon, hogy az intézmény tanítási gyakorlata minél hatékonyabb legyen. Hattie arra a következtetésre jutott, hogy a legeredményesebb az, ha a pedagógusok saját és kollégáik tanítási gyakorlatából tanulnak, tehát ők is „tanulókká” válnak (Hattie, 2009). Ez nyilván felveti az önreflektivitás kérdését is. Fullan szerint az egyéni 
szaktudás meghatározója az iskola fejlődési képességének, de szükségesek bizonyos szervezeti jellemzők is, mint például a „folyamatos megújulásra képes szakmai közösség”. Másképp fogalmazva: az egyéni képességeket csak az iskolán belüli kapcsolatok folyamatos fejlődése mellett lehet jól hasznosítani. Fullan új fogalmat is alkot a nevelötestület kollektív teljesítményére, a pedagógusok együttmüködésére. Ezt kollektív kapacitásnak nevezi. Szerinte a kollektív kapacitás kiemelkedő egyéni teljesítményt eredményez. Erre két okot sorol fel. Egyrészt az eredményesnek bizonyuló gyakorlatok elterjednek a nevelötestületben, másrészt a nevelötestület tagjai a közös tevékenységből adódóan erősen elkötelezettekké válnak, ami egy nagyfokú érzelmi elköteleződést, kollektív felelősség kialakulását jelenti (Fullan, 2010). A tanárok továbbra is önállóan dolgoznak, de a tantestület, a közösség tudása, támogatása rendelkezésükre áll. A tanárok önálló egyéniségek, de a tantestületben létezik egy közös „tudástár”, amelyet a közösen megfogalmazott célok eléréséért hasznosítanak (Hargreaves és Fullan, 2012). A legsikeresebb oktatási rendszerekben jellemző a tanárok közti szoros együttműködés, a tanárok egymástól való tanulása. Részt vesznek egymás óráin, elemzik a látottakat, támogatják egymás fejlődését. A folyamatos visszajelzések és a folyamatos önreflexió gyakorlása hozzájárul a tanárok folyamatos fejlődéséhez. Ugyanakkor figyelni kell arra, hogy egy-egy kollégára ne háruljon ebben a folyamatban túl nagy munkateher, mert ez konfliktushoz vezethet. Ez az intézményvezető felelőssége.

Felvetődik az a kérdés is, hogy az intézmény felszereltsége milyen hatással van a tanulói eredményességre. A Coleman-jelentés (1966) szerint ennek mérsékelt hatása van. Lehet gyenge színvonalú az oktatás kiváló infrastruktúrájú iskolában is, és lehet eredményes az oktatás egy rosszul felszerelt iskolában. Tehát az eredményesség nem kizárólag anyagi ráfordítás kérdése.

Fontos azt vizsgálni, hogy az iskola hogyan kezeli az innovációkat. David Hopkins szerint nem azok az iskolák a legeredményesebbek, amelyek a legtöbb innovációt fogadják be, hanem amelyek a lehetséges innovációk özönéből szelektálnak aszerint, hogy össze tudják-e hangolni azokat saját célirányos programjaikkal (David Hopkins, 1991).

Az angolszász világban az egyik leggyakrabban idézett modell a család-iskola-helyi közösség partnerkapcsolati modellje (Epstein, 2001). Ez a partnerkapcsolat támogatni képes a tanárokat munkájukban. Ha nincs partnerkapcsolat, és az iskola a családot külön entitásként kezeli, a szülő és az iskola nem tud harmonikusan együttműködni. Ha az iskola és a szülők közt valós az együttmüködés, akkor mindkét fél felismeri, hogy közös a felelősségük a gyermekek fejlődéséért. Epstein a következő bevonódási formákat említi: szülői feladatok ellátása, kommunikáció az iskolával, önkéntes feladatok az iskolában, az otthoni tanulás segítése, részvétel az iskolai szülői testületek munkájában, együttműködés más intézményekkel az iskola erőforrásainak gazdagítása céljából (Epstein, 2001). A valós partnerkapcsolat a szülőkkel pozitívan befolyásolja az iskola megítélését. 
Összegzésként tehát elmondható, hogy a kutatások egyik legkomplexebb kérdése az, hogy melyek pontosan az iskolai eredményesség kritériumai. Az oktatáseredményességi kutatások története körülbelül fél évszázados, és igen nagy utat tett meg. Míg kezdetben a kutatók azt hangsúlyozták, hogy az iskolák csak kisebb mértékben felelősek a tanulók eredményeiért, addig a mai kutatások többsége arra a következtetésre jutott, hogy az iskolának jóval jelentősebb szerepe van a tanulók fejlődésében, mint korábban hitték. Az összetettebb képalkotáshoz hozzájárultak azok az új mérési és számítási eszközök, statisztikai módszerek, amelyek pontosabban képesek mérni a hozzáadott értéket, az eredményességet. Rövid elméleti bevezetőnk célja az volt, hogy bemutassuk, hogy a kutatócsoport milyen irányban indult el, mely eredményességre ható tényezőket tartotta leginkább fókuszban, amikor a kutatás e területét megtervezte.

\section{Kutatás}

Kutatásunk célja, hogy feltárja a következőket:

1. A pedagógusok nézeteit, attitűdjét, motiváltságát az iskolai munkájukkal kapcsolatban.

2. A szülők elvárásait az iskolával szemben.

3. A szülők véleményét az iskolában folyó tevékenységekről.

4. Az egyetem és a gyakorlóiskola együttműködésének jellemzőit.

5. A gyakorlóiskola külső megítélését.

6. A gyakorlóiskolában folyó tevékenységek és az iskola külső megítélésének összefüggését.

A fenti célok alapján a következő hipotéziseket állítottuk fel:

H1: A gyakorlóiskola tanárainak többsége hatékonyan irányítja a tanítás-tanulás folyamatát. H2: A szülők az iskolaválasztásnál a gyakorlóiskolában folyó szakmai munka minőségét veszik elsősorban figyelembe.

H3: A szülők többsége elégedett a gyakorlóiskola pedagógusainak tevékenységével.

H4: A pedagógusok önreflektíven elemzik saját tevékenységüket, ezzel is példát mutatva a tanárjelölteknek.

H5: A pedagógusokban nagy igény van a szakmai fejlődésre.

H6: A pedagógusok motiváltak arra, hogy tudásukat megosszák kollégáikkal.

H7: Az egyetem és a gyakorlóiskola közötti szakmai együttműködés nem erős. 


\section{Eredmények}

\section{Hatékony vezetés}

Számos kutatás foglalkozott azzal a kérdéssel, hogy mi az oka annak, hogy valaki jó vezető vagy rossz vezető. Douglas McGregor (1966) megközelítésében a vezetés stílusát meghatározza, hogy a vezető miként gondolkozik a vezetettekről. McGregor azt feltételezte, hogy a vezetők alapvetően kétféle módon gondolkozhatnak azokról az emberekről, akiket irányítaniuk kell. Az X elmélet emberképe a felelősséget hárító, munkaerejével takarékoskodó embert mutat. Ha egy vezető így gondolkodik beosztottjairól, akkor a jutalmazás és büntetés eszközeiben bízik, és elengedhetetlennek tartja a szoros felügyeletet. Az így gondolkozó vezető a tekintélyelvűség híve.

Az Y elmélet ezzel szemben a motivációra épít, és emberképében fontos szerep jut az ambíciónak, a felelősségvállalásnak, az aktivitásnak. Az a vezető, aki az Y elméletben hisz, abban is hisz, hogy a beosztottak igénylik az önállóságot, meg lehet bennük bízni, és szükségtelen, hogy a vezető mindig a sarkukban járjon. Az Y elmélet a demokratikus vezetési stílusnak kedvez, melyről már tudjuk, hogy a részvételre, a vitára, a bizalomra és a szolidaritásra alapoz.

A beosztottakban ott vannak mind az X, mind az Y elmélet által feltételezett lehetőségek, és inkább a vezetői stílus az, ami önmagát beteljesítő jóslatként az egyik, illetve a másik elvárásrendszer következményeit felszínre hozza. Háromféle vezetési stílus jellemzőinek jelenlétét vizsgáltuk: az autoriter, a demokratikus és a ráhagyásos stílust.

Az autoriter módon vezetett csoportban a munka motivációja kívülről származik, amikor a vezető nem ellenőriz, a munkavégzés abbamarad. A feladatok rutinpályákat követnek, és hiányzik belőlük az eredetiség és a kreativitás. Egészében véve a kutatók azt találták, hogy az autoriter vezetés arra készteti az embert, hogy maradjon passzív, ne eredetieskedjen, és véleményét ne mondja ki.

A demokratikusan vezetett csoportban a munka motivációja magukból a tagokból származik, amit az bizonyít, hogy amikor a vezető elhagyja a helyszínt, a munka változatlanul folytatódik. A légkör barátságos és konstruktív, gyakori a kölcsönös dicséret, és hamar megjelenik a csoporttulajdon iránti respektus.

A ráhagyásos vezetési stílussal vezetett csoportban a tagok nem produkáltak túl sok eredményt, és ambíciótlanok voltak.

Mivel minőségi munkát az iskolában általában motivált tanárok végeznek, fontosnak tartottuk, hogy megvizsgáljuk, a vezetői munka és stílus hogyan befolyásolja azokat az iskolai körülményeket, amelyek közvetlen hatással vannak a tanárok teljesítményére. 


\begin{tabular}{|l|c|}
\hline $\begin{array}{l}\text { Az iskolavezetés munkájával kapcsolatos alábbi állítások közül } \\
\text { Ön melyekkel ért egyet? }\end{array}$ & egyetért \\
\hline $\mathbf{N}=\mathbf{1 1 3}$ & $64 \%$ \\
\hline $\begin{array}{l}\text { Minden közérdekű kérdésben a tantestület dönt nyilvános vita után, } \\
\text { a vezetőség támogatásával. (demokratikus) }\end{array}$ & $32 \%$ \\
\hline \begin{tabular}{l} 
Minden közérdekü döntést a vezetőség hoz. (autoriter) \\
\hline $\begin{array}{l}\text { A tantestület szabadon hozhat döntéseket, a vezetőség befolyása } \\
\text { nélkül. (ráhagyásos) }\end{array}$
\end{tabular} & $22 \%$ \\
\hline $\begin{array}{l}\text { A vezetőség szakmai anyagokat bocsájt rendelkezésre a tantestület } \\
\text { döntéseihez, és kérésre további információval szolgál, de a vitában } \\
\text { nem vesz részt. (ráhagyásos) }\end{array}$ & $46 \%$ \\
\hline $\begin{array}{l}\text { A feladatok elvégzése esetén a résztvevők szabadon választhatják } \\
\text { meg munkatársaikat, a munkamegosztás a csoport belső ügye. } \\
\text { (demokratikus) }\end{array}$ & $38 \%$ \\
\hline $\begin{array}{l}\text { A vezetőség hagyja, hogy mindenki olyan feladatot vállaljon, } \\
\text { amilyet akar, és a feladathoz saját maga válassza meg a munkatársait. } \\
\text { (ráhagyásos) }\end{array}$ & $23 \%$ \\
\hline $\begin{array}{l}\text { A vezetőség kijelöli mindenki számára a feladatot és az abban részt } \\
\text { vevő munkatársakat. (autoriter) }\end{array}$ & $74 \%$ \\
\hline A vezetőség objektivitásra törekedve dicsér és bírál. (demokratikus) \\
\hline $\begin{array}{l}\text { A vezetőség ritkán tesz észrevételt, nem értékel, nem szabályoz, de } \\
\text { a hozzá intézett kérdésekre készséggel válaszol. (ráhagyásos) }\end{array}$ & $68 \%$ \\
\hline
\end{tabular}

\section{1. táblázat: Vezetői stílusok megítélése}

Az eredmények alapján látható, hogy a legmagasabb értéket (74\%) egy autoriter vezetési jellemző mutat a feladatok kijelölése területén. Az objektív értékelés jelenléte is jól kimutatható a válaszokban (68\%), ami demokratikus vonás (1. táblázat). A harmadik legmagasabb értéket is egy demokratikus jellemző mutatja, 64\%-a a válaszadóknak azon a véleményen van, hogy minden közérdekü kérdésben a tantestület dönt nyilvános vita után, a vezetőség támogatásával (vö. 4. és 5. fejezet). Ennek viszont ellentmond a következö táblázat adata, ahol a pedagógusok válaszoltak arra, hogy milyen mértékben érzik szakmai kérdésekbe való bevonásukat. Erre mindössze 2,92-es átlag született (lásd. 2. táblázat). Viszonylag kevesen jelölték be a ráhagyásos vezetési stílus jellemzőit (22\%, 46\%, 23\%, 16\%). Ez arra enged következtetni, hogy az erre a stílusra jellemző vezetői viselkedés kevésbé van jelen. A vezetői magatartással való elégedettségüket ötfokú skálán véleményezték a pedagógusok. 


\begin{tabular}{|c|c|c|}
\hline \multicolumn{3}{|c|}{$\begin{array}{l}\text { Kérjük, határozza meg, hogy Ön mennyire elégedett az iskolavezetés munkájával } \\
\text { az alábbi területeken! }\end{array}$} \\
\hline$N=113$ & átlag & szórás \\
\hline Tervezettség & 3,88 & 0,084 \\
\hline Szervezettség & 3,66 & 0,085 \\
\hline Ellenőrzés, visszacsatolás & 3,65 & 0,087 \\
\hline Kommunikáció & 3,39 & 0,096 \\
\hline Pedagógusok motiválása & 3,33 & 0,098 \\
\hline $\begin{array}{l}\text { Egyenletes munkamegosztás } \\
\text { a tantestületen belül }\end{array}$ & 2,82 & 0,090 \\
\hline $\begin{array}{l}\text { Pedagógusok bevonása a szakmai } \\
\text { döntésekbe }\end{array}$ & 2,92 & 0,103 \\
\hline Új kezdeményezések felkarolása & 3,83 & 0,089 \\
\hline Következetes döntéshozatal & 3,54 & 0,100 \\
\hline $\begin{array}{l}\text { Alulról felfelé történő } \\
\text { kezdeményezések támogatása }\end{array}$ & 3,19 & 0,102 \\
\hline A kritika elfogadása & 3,07 & 0,108 \\
\hline Egyéni problémák megfelelő kezelése & 3,60 & 0,092 \\
\hline Problémaazonosítás & 3,58 & 0,091 \\
\hline Problémamegoldás & 3,50 & 0,095 \\
\hline Tanulás a problémákból & 3,43 & 0,098 \\
\hline Demokratikus légkör megteremtése & 3,26 & 0,112 \\
\hline Jutalmazás & 3,13 & 0,104 \\
\hline
\end{tabular}

\section{2. táblázat: Vezetői magatartás megítélése}

A vezetéssel kapcsolatos kérdésekre minden területen 3 és 4-es választ kaptunk 60\%-ban, ami egy semleges (elégedett is vagyok, meg nem is) véleményt takar. Sajnos sokan féltek a beazonosíthatóságtól, ahogyan a kérdőív végén ezt többen le is írták.

Az új kezdeményezések felkarolása és a tervezettség kapott magas értékeket, a legalacsonyabbat pedig az egyenletes munkamegosztás.

A kritika elfogadása, a pedagógusok bevonása a szakmai döntésekbe és a demokratikus légkör megteremtése kérdéseknél a válaszadók több mint 10\%-a elégedetlen, azaz 1-est jelölt. Ezt erősítik a szórásértékek is, hiszen a legnagyobb szórás a demokratikus légkör 
megteremtése területén szerepel, ezt követi a kritika elfogadása, majd a pedagógusok bevonása a szakmai döntésekbe.

A következő kérdésben nemcsak a vezetéssel kapcsolatos, hanem a légkörre utaló tényezőket is felsoroltunk, itt is ötfokú skálán történt a válaszadás.

\begin{tabular}{|l|l|}
\hline Kérjük, határozza meg, hogy Ön mennyire elégedett az alábbi tényezőkkel! \\
\hline $\mathbf{N}=\mathbf{1 1 3}$ & átlag \\
\hline Munkahelyi légkör & 3,66 \\
\hline Tantestületen belüli munkamegosztás & 2,97 \\
\hline A szervezet nyújtotta erkölcsi megbecsülés & 3,47 \\
\hline Teljesítményem objektív értékelése & 3,69 \\
\hline Az iskola vezetése & 3,35 \\
\hline
\end{tabular}

\section{3. táblázat: Munkahelyi légkör}

A tantestületen belüli munkamegosztásnál tapasztalható a leggyengébb átlag, míg a felsorolt tényezők közül a teljesítményük objektív megítélésével a legelégedettebbek a pedagógusok (3. táblázat).

A szakmai feladatok ellátását akadályozó tényezők között is előfordultak a vezetés munkájához kapcsolódó pontok.

\begin{tabular}{|l|c|c|c|}
\hline \multicolumn{1}{|l|}{ Mi akadályozza Önt szakmai feladatainak ellátásában? } \\
\hline $\mathbf{N}=\mathbf{1 1 3}$ & $\begin{array}{c}\text { egyáltalán } \\
\text { nem }\end{array}$ & ritkán & rendszeresen \\
\hline $\begin{array}{l}\text { Az iskolavezetés alacsony szintü } \\
\text { vezetői kompetenciái }\end{array}$ & 82 & 28 & 3 \\
\hline $\begin{array}{l}\text { Az iskolavezetéssel való } \\
\text { kommunikáció és együttműködés } \\
\text { hiánya }\end{array}$ & 42 & 60 & 11 \\
\hline
\end{tabular}

\section{4. táblázat: Vezetői kompetenciák}

Az iskolavezetéssel való kommunikáció ritkán akadályozó tényező a megkérdezett pedagógusok felénél (53,1\%), közel 10\%-uk viszont azt válaszolta, hogy ez rendszeresen akadályozza őket (4. táblázat). Összességében elmondható, hogy a pedagógusok többsége nem 
gondolja, hogy a vezetőségnek alacsony szintű vezetői kompetenciái lennének. Érdekes adat viszont, hogy a pedagógusok csupán egyharmad része érzi úgy, hogy az iskolavezetéssel való kommunikáció elégtelensége nem akadályozza szakmai feladatainak elláááában (vö. 8.fejezet).

A vezetői magatartás kihat az iskolai klímára, légkörre. Az iskolai klíma egy olyan hatásegyüttesnek tekinthető, amelyet a vezetői magatartás, az iskolai normák, célok, elvárások, az iskolai élet szereplöi színeznek egyedivé. A pedagógusokat, a tanulókat és a szülőket is megkérdeztük, milyennek látják, érzik az iskolai légkört. Válaszaikat ötfokú skálán jelölhették be.

\begin{tabular}{|l|c|c|c|}
\hline Mennyire jellemzőek az alábbi tulajdonságok az iskolára? \\
\hline $\mathbf{N}=\mathbf{1 1 3}$ & $\begin{array}{c}\text { pedagógusok } \\
\text { véleménye }\end{array}$ & tanulók véleménye & szülők véleménye \\
\hline kategóriák & \multicolumn{3}{|c|}{ átlag } \\
\hline demokratikus & 3,35 & 3,33 & 3,57 \\
\hline jól irányított & 4,02 & 3,73 & 3,88 \\
\hline közösségi & 3,90 & 4,05 & 4,15 \\
\hline korlátozó & 2,45 & 2,99 & 2,48 \\
\hline folyton változó & 3,30 & 2,77 & 2,58 \\
\hline nyitott a külvilágra & 4,25 & 3,92 & 4,06 \\
\hline rideg & 1,6 & 1,83 & 1,61 \\
\hline támogató & 4,07 & 3,84 & 3,87 \\
\hline fejlődésre ösztönző & 4,19 & 3,94 & 3,98 \\
\hline izgalmas, érdekes & 3,8 & 3,53 & 3,82 \\
\hline régimódi & 2,02 & 2,05 & 1,95 \\
\hline szórakoztató, bulis & 2,56 & 3,00 & 3,23 \\
\hline
\end{tabular}

\section{5. táblázat: Iskolai légkör}

Ha egymás mellett vizsgáljuk az egyes iskolai légkörre vonatkozó kérdésekben a pedagógusok, a tanulók és a szülők válaszainak átlagát, akkor azt tapasztaljuk, hogy a pedagógusok, a tanulók és a szülök az egyes kérdéseket hasonlóan ítélik meg, ami megerősíti az iskolai klímát külön fejezetben vizsgáló eredményeinket (5. táblázat) (vö. 5. fejezet). Az átlagok alapján a pedagógusok-tanulók-szülők az iskolát inkább fejlődésre ösztönzőnek, jól irányítottnak, támogatónak, a külvilágra nyitottnak, az iskolaközösséget jó közösségnek tartják. Nem tartják az iskolát ridegnek és régimódinak. 
Az adatok elemzése során felmerült, hogy az iskola pedagógusai a válaszadásoknál a „vezetés” szó alatt feltételezhetően nem ugyanazt értették. A vezetőség tagjai ugyanis az igazgatón kívül még négy igazgatóhelyettesből állnak, és a két épületnek is külön igazgatóhelyettesei vannak.

\section{A gyakorlóiskola legfontosabb feladatai}

Érdekelt bennünket az, hogy miket tartanak a pedagógusok a gyakorlóiskola legfontosabb feladatainak. A következő témakörökről kérdeztük meg a véleményüket: a diákok minél magasabb szintű felkészítése a felsőoktatási továbbtanulásra, szilárd erkölcsi értékek közvetítése, kimagasló szakmai színvonalú oktatás, az egyetemmel való kutatási együttműködés, a tanár szakos hallgatók magas színvonalú felkészítése szaktárgyuk tanítására, a legjobb képességű diákok képzése, nemzetközi szakmai együttműködésekben való közreműködés, minél sokszínűbb szabadidős tevékenységrendszer felkínálása, a diákok motiválása a kutatómunkára, szaktudományos tudás kialakítása, tanulmányi versenyeken való részvétel, a pedagógusok folyamatos pedagógiai fejlesztése, a pedagógusok szaktudományos képzése, részvétele tudományterületi kutatásokban, pedagógiai, pszichológiai témájú kutatásokban, pedagógiai fejlesztések, innovációk tervezése és megvalósítása, a lemaradó tanulók felzárkóztatása, a szülőkkel való szoros partneri együttműködés, a pedagógusok szakmai karrierjének támogatása, példamutatás más iskolák számára és pedagógiai fejlesztések, innovációk szakmai disszeminálása más iskolák számára.

A felsorolt témák mind részét képezik a gyakorlóiskolai munkának, de ahhoz, hogy a gyakorlóiskola szakmai fejlesztő iskolává váljon, nemcsak a hagyományos gyakorlóiskolai feladatokat kell végeznie, hanem megújulásra képes alkotóműhely kell hogy legyen, ahol a pedagógusokban igény van az innovációra és a kutatási tevékenységekre.

A válaszadók által legfontosabbnak tartott tíz feladatot tartalmazza a 6. táblázat. 


\begin{tabular}{|l|l|l|}
\hline \multicolumn{3}{|l|}{ Kérjük, értékelje az alábbi felsorolt célokat abból a szempontból, } \\
hogy Ön szerint melyek lehetnek a gyakorlóiskola legfontosabb feladatai! Válaszát \\
a megfelelo szám megadásával jelölje! [„1 = egyáltalán nem fontos”, „2 = inkább nem \\
fontos”, „3 = fontos is, meg nem is”, „4 = inkább fontos”, „5 = nagyon fontos”] \\
\hline $\mathbf{N}=\mathbf{1 0 2}$ & \multicolumn{1}{|c|}{ átlag } & \multicolumn{1}{c|}{ szórás } \\
\hline Kimagasló szakmai színvonalú oktatás & 4,83 & 0,447 \\
\hline $\begin{array}{l}\text { A tanár szakos hallgatók magas színvonalú } \\
\text { felkészítése szaktárgyuk tanítására }\end{array}$ & 4,75 & 0,516 \\
\hline Szilárd erkölcsi értékek közvetítése & 4,70 & 0,503 \\
\hline Példamutatás más iskolák számára & 4,55 & 0,640 \\
\hline $\begin{array}{l}\text { A diákok minél magasabb szintü felkészítése } \\
\text { a felsőoktatási továbbtanulásra }\end{array}$ & 4,54 & 0,640 \\
\hline A lemaradó tanulók felzárkóztatása & 4,54 & 0,539 \\
\hline $\begin{array}{l}\text { A szülőkkel való szoros és partneri } \\
\text { együttműködés }\end{array}$ & 4,50 & 0,576 \\
\hline A pedagógusok folyamatos pedagógiai fejlesztése & 4,42 & 0,696 \\
\hline Tanulmányi versenyeken való részvétel & 4,20 & 0,745 \\
\hline A pedagógusok szaktudományos képzése & 4,17 & 0,785 \\
\hline
\end{tabular}

\section{6. táblázat: A gyakorlóiskola legfontosabb feladatai}

A pedagógusok legfontosabbnak a kimagasló szakmai színvonalú oktatást tartják. Szintén magas átlagot kapott a tanár szakos hallgatók magas színvonalú felkészítése szaktárgyuk tanítására. Nem tartják annyira fontosnak a nemzetközi szakmai együttmüködésekben való közreműködést, illetve a részvételt tudományterületi vagy pedagógiai-pszichológiai kutatásokban (vö. 8. fejezet). Feltételezhető, hogy a pedagógusok nehezen tartják összeegyeztethetőnek az időigényes kutatómunkát a mindennapi iskolai feladatokkal. Leterheltségérzetük miatt nehezen tudnak a kutatómunkára időt szakítani. A nemzetközi szakmai együttműködés fontosságának alacsony átlagértéke feltételezhetően részben a nyelvtudás hiányára vezethető vissza. 
A pedagógusok gyakorlóiskolai feladatokról vallott nézetei mellett fontosnak tartottuk annak feltárását, hogy melyek azok a tényezők, amelyek akadályozzák őket feladataik magasabb színvonalú ellátásában.

\begin{tabular}{|c|c|c|c|}
\hline \multicolumn{4}{|c|}{$\begin{array}{l}\text { Mi akadályozza Önt szakmai feladatainak ellátásában? } \\
\text { Kérjük, gondolja végig, hogy az alábbi tényezők rendszeresen, ritkán vagy egyáltalán } \\
\text { nem akadályozzák Önt! [„2 = igen, rendszeresen akadályoz”, „1 = ritkán akadályoz”, } \\
\text { „0 = egyáltalán nem akadályoz”] }\end{array}$} \\
\hline & $\begin{array}{c}\text { Barkóczy } \\
\text { utca } \\
\text { (25 fó) }\end{array}$ & $\begin{array}{c}\text { Bartók } \\
\text { tér } \\
\text { (25 fó) }\end{array}$ & $\begin{array}{c}\text { Mindkét } \\
\text { épület } \\
\text { (14 fó) }\end{array}$ \\
\hline kategóriák & \multicolumn{3}{|c|}{ átlag } \\
\hline Saját túlterheltségem & 1,16 & 1,4 & 1,86 \\
\hline Saját motivációim alacsony szintje & 0,16 & 0,36 & 0,43 \\
\hline A tanulók magatartási problémái & 0,72 & 0,72 & 1,07 \\
\hline A tanulók sokfélesége & 0,24 & 0,24 & 0,29 \\
\hline A tanulók felkészületlensége & 1,12 & 0,68 & 1,00 \\
\hline A tanulók családi háttere & 0,72 & 0,40 & 0,71 \\
\hline $\begin{array}{l}\text { A szülőkkel való kommunikáció és együttműkö- } \\
\text { dés hiánya }\end{array}$ & 0,96 & 0,52 & 0,86 \\
\hline $\begin{array}{l}\text { A kollégák közötti kommunikáció és együttmü- } \\
\text { ködés hiánya }\end{array}$ & 0,76 & 0,68 & 0,64 \\
\hline A kollégák alacsony szintű szakmai kompetenciái & 0,16 & 0,28 & 0,00 \\
\hline A kollégák munkához való hozzáállása & 0,64 & 0,68 & 0,21 \\
\hline $\begin{array}{l}\text { Az iskolavezetés alacsony szintű vezetői } \\
\text { kompetenciái }\end{array}$ & 0,36 & 0,36 & 0,00 \\
\hline $\begin{array}{l}\text { Az iskolavezetéssel való kommunikáció és } \\
\text { együttműködés hiánya }\end{array}$ & 0,76 & 0,80 & 0,64 \\
\hline $\begin{array}{l}\text { Az egyetemi oktatókkal való kommunikáció és } \\
\text { együttmüködés hiánya }\end{array}$ & 0,56 & 0,28 & 0,36 \\
\hline A hallgatók felkészületlensége & 0,68 & 0,48 & 0,50 \\
\hline A hallgatók sokfélesége & 0,24 & 0,24 & 0,36 \\
\hline A fenntartó támogatásának hiánya & 0,56 & 0,44 & 0,64 \\
\hline
\end{tabular}

6.7. táblázat: Szakmai feladatok elvégzését akadályozó tényezők 
A két iskolaépület közötti ingázás jelentős terhet jelent a pedagógusoknak, 50\%-uk jelölte be, hogy rendszeresen akadályozza a feladatok ellátásában a saját túlterheltsége (7. táblázat). Érdekes, hogy az egy-egy épületben dolgozók nem érzik olyan mértékben akadályozó tényezőnek a tanulók magatartási problémáit, mint a két épület között ingázó kollégák. Az ő szüneteik azzal telnek, hogy a két iskolaépület közötti távot megtegyék, míg az egy-egy épületben dolgozóknak jobban van ideje a szünetben is a diákokkal beszélgetni, egy-egy magatartási problémát megoldani, kezelni. A szülőkkel való kommunikáció a Barkóczy úton nehézkesebb, ennek két oka lehet; a vidéki szülők nehezebben jönnek be fogadóórára, illetve a középiskolás korosztály szülei már kevésbé érdeklődőek, együttmüködőek, mint a kisebb gyermekekéi.

Egyáltalán nem jelent akadályt a szakmai feladatok ellátásában a tanulók és a hallgatók sokfélesége és saját motivációjuk alacsony szintje sem. A nagy többség (84\%) úgy ítéli meg, hogy motiváltsága nem alacsony szintű.

Az egyéb válaszok között ketten az infrastruktúra hiányosságait említik, ezek közül a körülményes eszközbeszerzésről és a megfelelő méretű és felszereltségű tanterem hiányáról írnak. Egy válasz szerint akadályozó tényező a pályázatokban való részvétel, a sok adminisztráció és a pedagógusok nagy leterheltsége, külön kiemelve a szaktanácsadók, szakértők által végzett munkát, amiért nem kapnak annyi munkaidő-kedvezményt, amennyivel többet dolgoznak. Ebből következik a válaszadó szerint, hogy sok az ingyenes munkavégzés. Egy másik válaszadó szerint a vezetőség nem hallgatja meg és nem fogadja el a pedagógusok szakmai véleményét, javaslatait. A tanulók leterheltségét, a 8., 9. és 10. órában végzett pedagógiai munka hatástalanságát említi két válaszadó. 
Fontosnak tartottuk annak feltárását, hogy melyek azok a tényezők, amelyek akadályozzák és segítik az iskola eredményességét. Erről a két kérdésről a pedagógusokat és a szülőket kérdeztük.

\begin{tabular}{|c|c|c|c|}
\hline \multicolumn{4}{|c|}{$\begin{array}{l}\text { Véleménye szerint az alábbi tényezők közül melyek segítik elő a leginkább } \\
\text { az iskola eredményességének növekedését? Kérjük, válasszon ki az alábbi tényezők } \\
\text { közül legfeljebb ötöt! [többszörös választás; ha megjelöli, „”-gyel kódolódik, ha nem, } \\
\text { akkor „0”-val (vagy üresen marad)] }\end{array}$} \\
\hline & $\begin{array}{c}\text { Barkóczy } \\
\text { utca } \\
(25 \text { fó) }\end{array}$ & $\begin{array}{c}\text { Bartók } \\
\text { tér } \\
\text { (25 fö) }\end{array}$ & $\begin{array}{c}\text { Mindkét } \\
\text { épület } \\
\text { (14 fö) }\end{array}$ \\
\hline kategóriák & \multicolumn{3}{|c|}{ százalékos gyakoriság (\%) } \\
\hline pedagógusok motiváltsága & 88 & 76 & 79 \\
\hline pedagógusok felkészültsége, képzettsége & 72 & 80 & 86 \\
\hline tanulók motiváltsága & 60 & 56 & 64 \\
\hline tanulók felkészültsége, hozott tudása & 16 & 24 & 14 \\
\hline támogató hozzáállás a család részéről & 28 & 40 & 50 \\
\hline csoportbontás lehetősége & 24 & 16 & 21 \\
\hline jó felszereltség, infrastruktúra & 60 & 64 & 50 \\
\hline színvonalas tehetséggondozás & 20 & 20 & 21 \\
\hline a tanulók személyre szabott támogatása & 44 & 40 & 29 \\
\hline közösen elfogadott és vallott célok és értékek & 48 & 48 & 50 \\
\hline komplex és jól használható pedagógiai program & 12 & 24 & 14 \\
\hline tantestületen belüli tudásmegosztás & 20 & 28 & 21 \\
\hline $\begin{array}{l}\text { az egyetem és a gyakorlóiskola szoros szakmai } \\
\text { együttmüködése }\end{array}$ & 24 & 28 & 36 \\
\hline $\begin{array}{l}\text { a gyakorlóiskola és a többi iskola szoros szakmai } \\
\text { együttműködése }\end{array}$ & 4 & 4 & 0 \\
\hline az iskola professzionális vezetése & 32 & 32 & 29 \\
\hline
\end{tabular}

\section{8. táblázat: Az alábbi tényezők közül melyek segítik elő a leginkább az iskola} eredményességének növekedését? 
Az iskola eredményességének növekedését segítő tényezők közül a pedagógusok motiváltságát (81\%) és felkészültségét (78\%) jelölték magas arányban a válaszadók (8. táblázat). Természetesen a jó felszereltség és infrastruktúra is nagy százalékban kapott jelölést: (59\%).

A tanulók felkészültsége, hozott tudása nem segiti (esetleg gátolja?) az eredményességet, hiszen ezt a válaszadók 19\%-a jelölte. Különösen kevesen jelölték ezt a Barkóczy úti épületben (16\%) és a mindkét épületben tanítók (14\%).

A komplex és jól használható pedagógiai programot 17\% jelölte. A legkevesebb jelölést a gyakorlóiskola és a többi iskola szoros szakmai együttműködése kapta (3\%).

A szülők véleménye az iskola színvonalának emelkedését segítő és akadályozó tényezőkről.

Ön szerint milyen mértékben akadályozzák vagy segítik az alábbi tényezők az iskola színvonalának emelkedését? 1 = nagymértékben akadályozza, 2 = inkább

akadályozza, 3 = részben akadályozza, részben segíti, 4 = inkább segíti, 5 = nagymértékben segíti

\begin{tabular}{|l|c|c|c|}
\hline kategóriák & átlag & $\begin{array}{c}\text { nem } \\
\text { befolyásolja }\end{array}$ & $\begin{array}{c}\text { nem tudom } \\
\text { megítélni }\end{array}$ \\
\hline a pedagógusok munkaterhelése & 2,26 & 6 & 34 \\
\hline a pedagógusok motiváltsága & 4,32 & 1 & 19 \\
\hline $\begin{array}{l}\text { a tanulók tudásszintje az iskolába } \\
\text { lépéskor }\end{array}$ & 3,97 & 20 & 17 \\
\hline a tanulók motiváltsága & 4,39 & 1 & 5 \\
\hline $\begin{array}{l}\text { a kiscsoportos, bontott csoportos } \\
\text { foglalkozások }\end{array}$ & $\mathbf{4 , 6 6}$ & 3 & 8 \\
\hline a tanórákhoz szükséges eszközök & 4,56 & 5 & 6 \\
\hline a tantermek berendezése & 4,25 & 14 & 7 \\
\hline az órarend & 3,79 & 8 & 13 \\
\hline az iskola infrastruktúrája & 4,40 & 5 & 19 \\
\hline
\end{tabular}

\section{9. táblázat: A szülők véleménye az iskola színvonalának emelkedését segítő és akadályozó tényezőkről}

A színvonal emelkedését a szülők a kiscsoportos, illetve a bontott csoportos foglalkozások lehetőségében látják. Emellett a tanórákhoz szükséges eszközök meglétét (222fó), a tantermek berendezését (197 fö), illetve az iskola infrastruktúráját (204 fö) jelölték be a szülők, mint az iskola színvonalát pozitívan befolyásoló tényezőket (9. táblázat).

A pedagógusok munkaterhelését 139 szülő akadályozó tényezőként jelölte be. 
A válaszadó szülők a következő hiányosságokat sorolták fel a gyakorlóiskola működésében:

A legtöbben (28fö) az udvar rendbehozatalát hiányolják. Ez valószínű, hogy a Bartók téri udvarra vonatkozik, mert portalanításról és sártalanításról tesznek említést. A menzai ellátás javítása is gyakori téma volt (27 fô), illetve a menza korszerűsítése. Nagy számban kritizálják a szülők a gyerekek leterheltségét ( 9 fö), a tanárok leterheltségét (8 fó) és a rossz órarendet (14 fó), ami lyukasórákat és délutáni órákat tartalmaz, ebből fakadólag a gyerekek későn járnak haza, és már fáradtak tanulni. 7-en kifogásolják a folyosói öltözőszekrények állapotát és azt, hogy a gyerekek értékeiket nem tudják elzárni. 6-an a higiéniai hiányosságokra hívják fel a figyelmet: sokszor nincs szappan vagy egészségügyi papír a mosdóban. 6-an szeretnének magasabb szintű informatikaoktatást, 3-an több és jobb nyelvoktatást, több sportlehetőséget, táborozást és kirándulást a gyerekeknek, modernebb pedagógiai módszereket, és szükségét látják a szülőkkel való jobb kommunikációnak. 8-an nem találják elegendőnek a korrepetálások számát. 6 válaszadó szerint nem történik meg a nem megfelelő tanárok eltávolítása az iskolából.

Ezeken a hiányosságokon kívül még 1-2 említés történik a következő problémákról: a nem elégséges tehetséggondozásról, a gyakori tanárváltásokról, arról, hogy csak kiválasztott osztályok használhatják a modern eszközöket, illetve arról, hogy a tornatermek zsúfoltak, egyszerre több osztálynak van órája bennük, szükség lenne új teremre. Előfordul, hogy tanárhiányzás esetén nem megy be helyettes az órára. Megemlítik a nagy osztálylétszámokat, kis csoportos foglalkozásokat szeretnének. Több csoportbontásra van szükség, például matematikából. A napköziben szeretnék, ha 1 napközis nevelö foglalkozna a gyerekekkel. Említésre kerül az épületek korszerüsítése, a tantermek korszerűsítése, a padok rossz állapota, a polcok, szekrények, függönyök hiánya, az elromlott projektorok javításának elmaradása. Van, aki szeretne nyílt órát látogatni gyermeke osztályában. Megemlítik, hogy a hallgatók által tartott órák hiányosságait nem pótolja be a vezetőtanár. Feszítettnek érzik a tempót, a szünetre nem tartják jónak házi feladat feladását. A szombati tanítási napokat is kritika éri. Javítani kell a tanulószoba minőségén. Szigorúbb ellenőrzés szükséges a portánál, gyakorlatilag bárki bejöhet. A nevelési problémák megoldására nagyobb hangsúlyt kell fektetni: foglalkozni kell az agresszió, a konfliktusmegoldás problémáival. Több szabadidős programra és beszélgetésre van szükség. Több házi versenyre, szakkörre, differenciált foglalkozásra van igény. A két épület között ne kelljen a diákoknak átjárni. Kritika éri az OFI-s tankönyveket, le szeretnék cserélni színvonalasabbra. A fogadóórán mindig legyenek ott a tanárok. A gimnáziumból szűrjék ki a nem odaillő diákokat, és a gimnázium előtt ne dohányozhassanak.

A pedagógusoktól megkérdeztük, hogy mely célok a legfontosabbak számukra a tanulók kompetenciáinak fejlesztése során, majd megkérdeztük, hogy a gyakorlatukban hogyan érvényesítik ezt. Milyen pedagógiai elképzeléseik vannak a tudásközvetítés módjairól? 
Milyen nézeteik vannak a tanításról-tanulásról? Milyen megközelítések dominálnak pedagógiai kultúrájukban?

Kérjük, válaszoljon az alábbi kérdésekre, melyek arra vonatkoznak, hogy az adott pedagógiai célok hogyan jelennek meg az Ön tanítási gyakorlatában! Kérjük, értékelje elsőként azt, hogy mennyire tartja fontosnak az adott cél megvalósítását a tanulók kompetenciáinak fejlesztésében! Válaszát a megfelelő szám megadásával jelölje! [ „1 = egyáltalán nem tartom fontosnak”, „2 = inkább nem tartom fontosnak”, „3 = fontosnak is tartom, meg nem is”, „4 = inkább fontosnak tartom”, „5 = nagyon fontosnak tartom”]

\begin{tabular}{|l|c|c|c|}
\hline kategóriák & $\begin{array}{c}\text { Barkóczy } \\
\text { utca } \\
\mathbf{( 2 5} \mathbf{f o})\end{array}$ & $\begin{array}{c}\text { Bartók } \\
\text { tér } \\
(\mathbf{2 5} \text { fö) }\end{array}$ & $\begin{array}{c}\text { Mindkét } \\
\text { épület } \\
(\mathbf{1 4} \text { fö) }\end{array}$ \\
\hline Információk szerzése és megjegyzése & 4,24 & 4,28 & 4,00 \\
\hline Fogalmak elsajátítása & 4,24 & 3,84 & 3,79 \\
\hline Készségek és képességek elsajátítása & $\mathbf{4 , 6 4}$ & $\mathbf{4 , 7 2}$ & $\mathbf{4 , 7 1}$ \\
\hline Gondolkodás fejlesztése & $\mathbf{4 , 7 6}$ & $\mathbf{4 , 7 2}$ & $\mathbf{4 , 7 9}$ \\
\hline A tanulók aktív tevékenysége & $\mathbf{4 , 8 0}$ & $\mathbf{4 , 8 0}$ & $\mathbf{4 , 7 1}$ \\
\hline $\begin{array}{l}\text { Az egyéni tanulási képességekhez, adottságokhoz } \\
\text { való alkalmazkodás }\end{array}$ & 4,40 & 4,64 & 4,71 \\
\hline A tanulók tanulási tevékenységének szabályozása & 3,96 & 3,56 & 3,93 \\
\hline $\begin{array}{l}\text { Az egyes tanulók optimális teljesítményéhez } \\
\text { szükséges feltételek megteremtése }\end{array}$ & 4,32 & 4,64 & 4,57 \\
\hline
\end{tabular}

\subsection{0. táblázat: A tanárok pedagógiai kultúrája}

A pedagógusok legfontosabbnak a tanulók aktív tevékenységét látják a tanítási gyakorlatukban (84\%) (10. táblázat). Magas értéket kapott még a gondolkodás fejlesztése, valamint a készségek és képességek elsajátítása. Meglepő, hogy a fogalmak elsajátítását 29\% nem tartja fontosnak. Figyelemreméltó, hogy amíg a gyakorlóiskola legfontosabb feladataira vonatkozó kérdésnél a legjobb képességű diákok képzése alacsony értékkel szerepelt, addig ennél a kérdésnél a pedagógusok többsége nagyon fontosnak vagy inkább fontosnak tartja az egyes tanulók optimális teljesítményéhez szükséges feltételek megteremtését (113 főből 59, illetve 42). 
Kértük a pedagógusokat, jelöljék be, milyen gyakran alkalmazzák az előzőeket a saját munkájuk során.

\begin{tabular}{|c|c|c|c|}
\hline \multicolumn{4}{|c|}{$\begin{array}{l}\text { Ezt követően kérjük, értékelje azt is, hogy Ön milyen gyakran alkalmazza az adott } \\
\text { megközelítést a saját gyakorlatában! [„1 = soha”, „2 = az óráim kevesebb mint felén”, } \\
\text { „3 = az óráim felén”, „4 = az óráim több mint felén”, „5 = minden órámon”] }\end{array}$} \\
\hline kategóriák & $\begin{array}{l}\text { Barkóczy } \\
\text { utca } \\
(25 \text { fö })\end{array}$ & $\begin{array}{l}\text { Bartók } \\
\text { tér } \\
(25 \text { fó) }\end{array}$ & $\begin{array}{l}\text { Mindkét } \\
\text { épület (14 } \\
\text { fó) }\end{array}$ \\
\hline Információk szerzése és megjegyzése & 4,20 & 4,24 & 3,86 \\
\hline Fogalmak elsajátítása & 4,08 & 3,84 & 3,57 \\
\hline Készségek és képességek elsajátítása & 4,32 & 4,76 & 4,21 \\
\hline Gondolkodás fejlesztése & 4,60 & 4,72 & 4,50 \\
\hline A tanulók aktív tevékenysége & 4,40 & 4,72 & 4,57 \\
\hline $\begin{array}{l}\text { Az egyéni tanulási képességekhez, adottságokhoz } \\
\text { való alkalmazkodás }\end{array}$ & 3,80 & 4,20 & 4,07 \\
\hline A tanulók tanulási tevékenységének szabályozása & 3,84 & 4,00 & 4,07 \\
\hline $\begin{array}{l}\text { Az egyes tanulók optimális teljesítményéhez szük- } \\
\text { séges feltételek megteremtése }\end{array}$ & 3,64 & 4,16 & 4,00 \\
\hline
\end{tabular}

\subsection{1. táblázat: Pedagógiai célok megvalósulása a gyakorlatban}

A célok és a gyakorlatban való alkalmazás teljes összhangban van, az előző kérdésben megjelölt legfontosabb célokat igyekszenek megvalósítani a munkájuk során a pedagógusok (11. táblázat).

Az adatok alapján látható, hogy a két épületben tanító tanárok pedagógiai gondolkodása között viszonylag nagy különbség van. A következő kérdések terén a Bartók téri pedagógusok gyakrabban törekszenek a modernebb pedagógiai eljárások alkalmazására: az egyes tanulók optimális teljesítményéhez szükséges feltételek megteremtése, a tanulók aktív tevékenysége, készségek és képességek elsajátítása.

A pedagógusok megfelelő önértékelése is fontos a megfelelö színvonalú munkához, a hatékony tanításhoz. A magas színvonalú tanítás feltétele, hogy a pedagógus tervezze meg a tanítás folyamatát, készüljön az óráira, majd minden óra után korrigálja a saját munkáját. 


\begin{tabular}{|c|c|c|c|}
\hline \multicolumn{4}{|c|}{$\begin{array}{l}\text { Kérjük, értékelje az alábbi állításokat aszerint, hogy azok mennyire jellemzőek Önre } \\
\text { szakmai tevékenysége során! [„1 = egyáltalán nem jellemző rám” „2 = inkább nem } \\
\text { jellemző rám” „3 = jellemző is rám, meg nem is” „4 = inkább jellemzo rám” „5 = teljes } \\
\text { mértékben jellemző rám”] }\end{array}$} \\
\hline kategóriák & $\begin{array}{c}\text { Barkóczy } \\
\text { utca } \\
(25 \text { fó })\end{array}$ & $\begin{array}{c}\text { Bartók } \\
\text { tér } \\
(25 \text { fó) }\end{array}$ & $\begin{array}{l}\text { Mindkét } \\
\text { épület } \\
\text { (14 fó) }\end{array}$ \\
\hline Kiváló szaktudással rendelkezem. & 4,44 & 4,24 & 4,50 \\
\hline $\begin{array}{l}\text { Nyomon követem a pedagógiai, pszichológiai, } \\
\text { módszertani szakirodalmat. }\end{array}$ & 3,88 & 3,64 & 3,93 \\
\hline Minden órámra óravázlattal/tervezettel készülök. & 3,92 & 3,60 & 3,64 \\
\hline $\begin{array}{l}\text { Minden órám után átgondolom az óra sikeres } \\
\text { és kevésbé sikeres részeit, és tanulságokat } \\
\text { fogalmazok meg magamnak. }\end{array}$ & 4,44 & 4,28 & 4,50 \\
\hline $\begin{array}{l}\text { Tudom korrigálni saját pedagógiai } \\
\text { tevékenységemet. }\end{array}$ & 4,76 & 4,48 & 4,57 \\
\hline Szívesen tartanék bemutatóórát kollégáknak. & 3,60 & 3,24 & 2,93 \\
\hline $\begin{array}{l}\text { Szívesen tartanék mühelyfoglalkozásokat } \\
\text { kollégáknak. }\end{array}$ & 3,48 & 3,40 & 3,14 \\
\hline $\begin{array}{l}\text { Munkámat értékesnek érzem az intézmény } \\
\text { életében. }\end{array}$ & 4,48 & 4,24 & 4,21 \\
\hline $\begin{array}{l}\text { Változatos értékelési formákat és eszközöket } \\
\text { alkalmazok. }\end{array}$ & 4,16 & 4,24 & 4,21 \\
\hline Keresem a folyamatos tanulás lehetőségeit. & 4,40 & 4,28 & 4,64 \\
\hline
\end{tabular}

\subsection{2. táblázat: Pedagógusok önértékelése}

Érdekes, hogy amíg 92\% kiválónak érzi szaktudását, addig csak 46, 9\% vállal bemutatóórát, illetve megközelítőleg a válaszolók fele (50,4\%) műhelyfoglalkozást, tehát a tudásmegosztás vágya kevésbé erősen van jelen (12. táblázat).

Elgondolkodtató az, hogy a 113 főből csak 70 válaszolta azt, hogy az óráira óravázlattal vagy óratervvel való készülés teljes mértékben vagy inkább jellemző rá. 
Vizsgáltuk, mennyire figyelnek a pedagógusok a tanítás folyamatában részt vevők visszajelzéseire. Érdekelt bennünket az, hogy elég nyitottak-e a kollégák, a tanulók, a szülők, a hallgatók, az iskolavezetés és az egyetemei oktatók visszajelzéseire. A tanári reflexió feltétele olyan érett, autonóm egyéniség, amelynek megléte esetén a pedagógusok képesek kritikai elemzés alá vonni saját munkájukat.

Kérjük, értékelje az alábbi állításokat aszerint, hogy azok mennyire jellemzőek Önre szakmai tevékenysége során! [„1 = egyáltalán nem jellemző rám”, „2 = inkább nem jellemző rám”, „3 = jellemző is rám, meg nem is”, „4 = inkább jellemző rám”, „5 = teljes mértékben jellemző rám”]

\begin{tabular}{|l|c|c|c|}
\hline kategóriák & $\begin{array}{c}\text { Barkóczy } \\
\text { utca } \\
(\mathbf{2 5} \mathbf{f o})\end{array}$ & $\begin{array}{c}\text { Bartók } \\
\text { tér } \\
(\mathbf{2 5} \text { fó) }\end{array}$ & $\begin{array}{c}\text { Mindkét } \\
\text { épület } \\
(\mathbf{1 4} \text { fó) }\end{array}$ \\
\hline Fontosak számomra a gyerekek visszajelzései. & 4,84 & 4,84 & 4,79 \\
\hline Fontosak számomra a szülők visszajelzései. & 4,48 & 4,64 & 4,50 \\
\hline Fontosak számomra a kollégák visszajelzései. & 4,52 & 4,48 & 4,57 \\
\hline $\begin{array}{l}\text { Fontosak számomra az iskolavezetés } \\
\text { visszajelzései. }\end{array}$ & 4,56 & 4,40 & 4,50 \\
\hline $\begin{array}{l}\text { Fontosak számomra az egyetemi oktatók } \\
\text { visszajelzései. }\end{array}$ & 4,00 & 3,84 & 4,14 \\
\hline Fontosak számomra a tanárjelöltek visszajelzései. & 4,24 & 3,92 & 4,29 \\
\hline
\end{tabular}

\subsection{3. táblázat: Tanári reflexió}

Kiugróan magas azon válaszadók száma, akik számára fontosak a gyerekek visszajelzései (13. táblázat). A szülők, kollégák, iskolavezetés, egyetemi oktatók, tanárjelöltek véleményének fontossági rangsorában a szülők állnak a legelső helyen. A kitöltők között a nem vezetőtanárként dolgozóknak nincs kapcsolata az egyetemi oktatókkal, illetve a tanárjelöltekkel, ebből az adatból tehát nem vonhatunk le következtetéseket. 
A tanítás hatékonyságáról, a tanulás támogatásáról kérdeztük a diákokat.

\begin{tabular}{|c|c|c|}
\hline \multicolumn{3}{|c|}{$\begin{array}{l}\text { Kérjük, gondold végig, hogy a gyakorlóiskolai tanórákra ÁLTALÁBAN } \\
\text { mennyire jellemzőek az alábbi állítások! } 1 \text { = egyáltalán nem jellemző, } \\
2 \text { = inkább nem jellemző, } 3 \text { = jellemző is, meg nem is, } 4 \text { = inkább jellemző, } \\
5 \text { = teljes mértékben jellemző }\end{array}$} \\
\hline kategóriák & $\begin{array}{l}\text { Barkóczy utca } \\
\text { (138 fó) }\end{array}$ & $\begin{array}{c}\text { Bartók tér } \\
(117 \text { fó) }\end{array}$ \\
\hline & \multicolumn{2}{|c|}{ átlag } \\
\hline Az órák érdekesek. & 2,99 & 3,28 \\
\hline Az órák változatosak. & 3,07 & 3,21 \\
\hline A tanárok magyarázatai érthetőek. & 3,30 & 3,86 \\
\hline A tanárok kérdéseit könnyű megválaszolni. & 3,26 & 3,11 \\
\hline $\begin{array}{l}\text { A dolgozatok azt kérik számon, amit megtanul- } \\
\text { tunk az órán. }\end{array}$ & 3,25 & 3,85 \\
\hline $\begin{array}{l}\text { Az órák alatt kapok szóbeli visszajelzéseket is } \\
\text { a tanároktól. }\end{array}$ & 3,33 & 3,67 \\
\hline A tanáraim nyitottak az új ötletekre. & 3,35 & 3,72 \\
\hline
\end{tabular}

\subsection{4. táblázat: A diákok véleménye a tanítás hatékonyságáról}

Elgondolkodtató, hogy a pedagógusok saját munkájukat sokkal kedvezőbb színben látják szaktudásuk és pedagógiai tevékenységük megítélésekor, mint ahogy a tanulók megítélik a tanítási órákon zajló munkát (14. táblázat). A tanulók közepesre értékelik az órák érdekességét (vö. 5. fejezet), változatosságát, a pedagógusok magyarázatainak érthetőségét, a számonkérések korrektségét és a pedagógusok nyitottságát. Ez egy gyakorlóiskolához képest gyenge teljesítmény. Természetesen ilyenkor az összes tanórájára gondol a tanuló, miközben megjelöli az egyes sorokban az értékelését. Vannak számára érdekesebb, izgalmasabb órák, és vannak, melyek kevésbé varázsolják el.

Megkérdeztük a tanulókat, hogy az órákon milyen lehetőségek vannak a kreatív vagy a problémamegoldó gondolkodás fejlődésére, van-e valódi kommunikáció pedagógus és tanuló között a tanulás során, és elég érdekesek-e az órák. 


\begin{tabular}{|c|c|c|}
\hline \multicolumn{3}{|c|}{$\begin{array}{l}\text { Kérjük, gondold végig, hogy a gyakorlóiskolai tanórákra ÁLTALÁBAN } \\
\text { mennyire jellemzőek az alábbi állítások! } 1 \text { = egyáltalán nem jellemző, } \\
2 \text { = inkább nem jellemző, } 3 \text { = jellemző is, meg nem is, } 4 \text { = inkább jellemzo, } \\
5 \text { = teljes mértékben jellemző }\end{array}$} \\
\hline & $\begin{array}{c}\text { Barkóczy utca } \\
\text { (138 fó) }\end{array}$ & $\begin{array}{c}\text { Bartók tér } \\
(117 \text { fó) }\end{array}$ \\
\hline kategóriák & \multicolumn{2}{|c|}{ átlag } \\
\hline $\begin{array}{l}\text { A tanárok biztatnak minket új megoldások } \\
\text { keresésére. }\end{array}$ & 3,38 & 3,87 \\
\hline $\begin{array}{l}\text { Úgy érzem, az iskolában tanultakra nincs szük- } \\
\text { ség a hétköznapokban. }\end{array}$ & 2,88 & 2,54 \\
\hline $\begin{array}{l}\text { Gyakran vagyunk lemaradva a tanulásban, ezért } \\
\text { sietnünk kell az anyaggal. }\end{array}$ & 2,92 & 2,80 \\
\hline $\begin{array}{l}\text { Van lehetőségünk arra, hogy az órai munka } \\
\text { során önálló döntéseket hozzunk. }\end{array}$ & 3,09 & 3,28 \\
\hline $\begin{array}{l}\text { Pontosan úgy kell végrehajtanunk a feladatokat, } \\
\text { ahogyan azt a tanár akarja. }\end{array}$ & 3,38 & 3,51 \\
\hline Az órai feladatok nem kötik le a figyelmemet. & 2,82 & 2,74 \\
\hline $\begin{array}{l}\text { Úgy érzem, fontos dolgokat tanulunk } \\
\text { az iskolában. }\end{array}$ & 3,04 & 3,50 \\
\hline $\begin{array}{l}\text { A tanárokat érdekli, hogy a diákok mit gondol- } \\
\text { nak egy témáról. }\end{array}$ & 3,15 & 3,48 \\
\hline $\begin{array}{l}\text { Mindig megpróbáljuk a dolgokat több nézőpont- } \\
\text { ból megvizsgálni. }\end{array}$ & 3,13 & 3,50 \\
\hline
\end{tabular}

\subsection{5. táblázat: A tanulás támogatása}

Az adatok alapján az iskola tanárainak támogató attitűdjét érzékelik a leginkább a tanulók az új megoldások keresésére. Érdekesség, hogy a Bartók téri épületben a legtöbb kérdésnél jobb átlag született, mint a Barkóczy utcai épületben (15. táblázat). A Bartók téri épületben tehát a tanulói visszajelzések alapján a pedagógusok nagyobb mértékben figyelnek arra, hogy a tanulók kreativitását, problémamegoldó gondolkodását fejlesszék.

Kutatásunk során kíváncsiak voltunk arra, mennyire érzik modernnek a tanulók a tanórákon használt módszereket. 


\begin{tabular}{|l|c|c|}
\hline \multicolumn{1}{|c|}{ Szerinted a tanáraitok a legmodernebb módszerekkel tanítanak Titeket? } \\
\hline & $\begin{array}{c}\text { Barkóczy utca } \\
(\mathbf{1 3 8} \text { fó) }\end{array}$ & $\begin{array}{c}\text { Bartók tér } \\
(\mathbf{1 1 7} \text { fó) }\end{array}$ \\
\hline kategóriák & \multicolumn{2}{|c|}{ százalékos gyakoriság (\%) } \\
\hline igen & 34,06 & 58,12 \\
\hline nem & 26,09 & 16,24 \\
\hline nem tudom & 39,85 & 25,64 \\
\hline
\end{tabular}

\subsection{6. táblázat: Tanórákon használt módszerek}

A Bartók téren tanuló diákok több mint fele úgy gondolja, hogy a tanárok a legmodernebb módszerekkel tanítják őket (16. táblázat). A Barkóczy utcai épületben a tanulók több mint egyharmada nem tudja megítélni, hogy mennyire újszerủek a tanárok módszerei, $34,06 \%$ viszont elég modernnek találja azokat.

Fontos kérdésnek tartottuk, hogy a tanulók hogyan viszonyulnak a különböző tanulásszervezési módokhoz, a pár- és csoportmunkához, a projektmunkához, a kiselőadás-, illetve prezentációkészítéshez, a vitamódszerhez. Ezek akkor alkalmazhatók hatékonyan, ha a pedagógus tisztában van az előnyökkel, hátrányokkal, azokkal a nehézségekkel, amelyek felmerülhetnek, és kezelni tudja a problémahelyzeteket.

\begin{tabular}{|l|c|c|c|c|c|}
\hline \multicolumn{1}{|l|}{ Mennyire szeretsz részt venni az alábbi tanórai tevékenységekben? } \\
\hline $\mathbf{N}=\mathbf{2 5 5}$ & \multicolumn{5}{|c|}{ százalékos gyakoriság (\%) } \\
\hline $\begin{array}{c}\text { kgyálta- } \\
\text { lán nem } \\
\text { kzeretem }\end{array}$ & $\begin{array}{c}\text { inkább } \\
\text { nem } \\
\text { szeretem }\end{array}$ & $\begin{array}{c}\text { szeretem } \\
\text { is, meg } \\
\text { nem is }\end{array}$ & $\begin{array}{c}\text { inkább } \\
\text { szeretem, } \\
\text { mint nem }\end{array}$ & $\begin{array}{c}\text { nagyon } \\
\text { szeretem }\end{array}$ \\
\hline $\begin{array}{l}\text { csoportban oldunk } \\
\text { meg feladatokat }\end{array}$ & 6,7 & 9,0 & 23,9 & 33,3 & 27,1 \\
\hline $\begin{array}{l}\text { párban oldunk meg } \\
\text { feladatokat }\end{array}$ & 3,1 & 8,6 & 19,6 & 37,6 & 31,0 \\
\hline
\end{tabular}

\subsection{7. táblázat: Tanórai tevékenységek}

A megkérdezett tanulók nagy része kedveli, ha csoportban vagy párosan dolgozhat (17. táblázat). 


\begin{tabular}{|c|c|c|c|c|c|}
\hline \multicolumn{6}{|c|}{ Mennyire szeretsz részt venni az alábbi tanórai tevékenységekben? } \\
\hline $\mathrm{N}=255$ & \multicolumn{5}{|c|}{ százalékos gyakoriság (\%) } \\
\hline kategóriák & $\begin{array}{l}\text { egyálta- } \\
\text { lán nem } \\
\text { szeretem }\end{array}$ & $\begin{array}{c}\text { inkább } \\
\text { nem } \\
\text { szeretem }\end{array}$ & $\begin{array}{l}\text { szeretem } \\
\text { is, meg } \\
\text { nem is }\end{array}$ & $\begin{array}{c}\text { inkább } \\
\text { szeretem, } \\
\text { mint nem }\end{array}$ & $\begin{array}{l}\text { nagyon } \\
\text { szeretem }\end{array}$ \\
\hline $\begin{array}{l}\text { egyedül oldunk } \\
\text { meg feladatokat }\end{array}$ & 8,2 & 18,0 & 34,5 & 26,3 & 12,9 \\
\hline $\begin{array}{l}\text { valamilyen projekt- } \\
\text { feladatot végzünk }\end{array}$ & 8,6 & 14,9 & 32,9 & 22,7 & 20,8 \\
\hline $\begin{array}{l}\text { több napig együtt } \\
\text { dolgozunk vala- } \\
\text { milyen témán } \\
\text { (témahét) }\end{array}$ & 14,5 & 11,0 & 35,7 & 23,5 & 15,3 \\
\hline kiselöadást tartok & 23,9 & 17,3 & 27,1 & 19,2 & 12,5 \\
\hline $\begin{array}{l}\text { prezentációt készí- } \\
\text { tek és mutatok be }\end{array}$ & 18,4 & 18,0 & 31,4 & 18,4 & 13,7 \\
\hline $\begin{array}{l}\text { vitatkozunk egy } \\
\text { témáról }\end{array}$ & 16,5 & 21,6 & 27,1 & 20,4 & 14,5 \\
\hline
\end{tabular}

\subsection{8. táblázat: Tanórai tevékenységek népszerüsége a diákok körében}

A többi munkaforma között nincs olyan, amelyet kimagaslóan szeretnének vagy elutasítanak a tanulók, a válaszok egyenletesen oszlanak el az ötfokú skálán (18. táblázat).

Következő kérdésünk arra vonatkozott, hogy a pedagógusok milyen eszközöket és milyen gyakorisággal használnak. Ezen belül érdekelt bennünket, hogy mennyire van jelen az IKT-eszközök használata a mindennapi tevékenységekben. 


\begin{tabular}{|c|c|c|c|c|}
\hline \multicolumn{5}{|c|}{$\begin{array}{l}\text { Milyen gyakran használjátok az alábbi eszközöket a tanórák során? } 1 \text { = soha, } \\
2 \text { = félévente egyszer-kétszer, } 3 \text { = havonta, } 4 \text { = hetente, } 5 \text { = naponta egyszer, } \\
6 \text { = naponta többször }\end{array}$} \\
\hline & \multicolumn{2}{|c|}{$\begin{array}{c}\text { Barkóczy utca } \\
\text { (138 fö) }\end{array}$} & \multicolumn{2}{|c|}{$\begin{array}{c}\text { Bartók tér } \\
\text { (117 fö) }\end{array}$} \\
\hline kategóriák & átlag & szórás & átlag & szórás \\
\hline $\begin{array}{l}\text { krétával, filccel } \\
\text { írható tábla }\end{array}$ & 5,39 & 0,108 & 5,35 & 0,117 \\
\hline interaktív tábla & 4,04 & 0,170 & 3,71 & 0,146 \\
\hline projektor & 5,59 & 0,068 & 5,34 & 0,091 \\
\hline okostelefon & 2,85 & 0,142 & 3,35 & 0,141 \\
\hline tanulói laptop & 1,58 & 0,094 & 3,49 & 0,107 \\
\hline tablet & 1,20 & 0,064 & 1,66 & 0,115 \\
\hline szavazórendszer & 1,38 & 0,073 & 2,14 & 0,112 \\
\hline
\end{tabular}

6.19. táblázat: Tanulást segítő eszközök

A projektor, a kréta és a tábla vezeti az eszközök listáját, ezeket használják leggyakrabban a tanárok (19. táblázat). A modernebb eszközök - tablet, tanulói laptop, szavazórendszer szinte sosem kerül elö, esetleg félévente egyszer. Felmerül a kérdés, hogy azért nem, mert a pedagógusok nem hajlandóak megújulni és használni ezeket az eszközöket, vagy nem állnak rendelkezésre ezek az eszközök.

Arra a kérdésre is kerestük a választ, hogy a szülők milyen szempontokat tartanak fontosnak az iskolaválasztás előtt, majd azt vizsgáltuk, mennyire elégedettek most ezekkel a tényezőkkel. Az iskolaválasztás előtti szempontokat egy 3-fokú skálán kellett értékelniük ( 1 = nem fontos, 2 = közepesen fontos, 3 = nagyon fontos), míg az elégedettséget egy ötfokú skálán kellett bejelölni ( 1 = egyáltalán nem vagyok elégedett, 2 = inkább nem vagyok elégedett, 3 = elégedett is vagyok, meg nem is, 4 = inkább elégedett vagyok, $5=$ teljes mértékben elégedett vagyok). 


\begin{tabular}{|c|c|c|c|}
\hline & 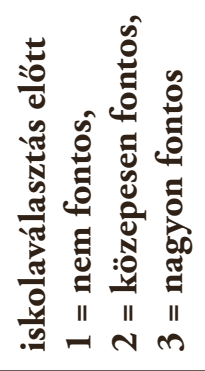 & 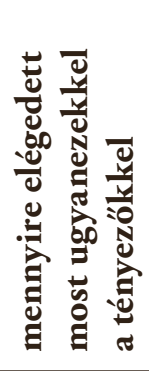 & 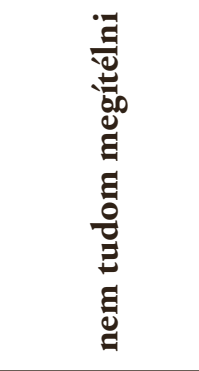 \\
\hline $\mathbf{N}=247$ & átlag & átlag & $\begin{array}{c}\text { gyakoriság } \\
\text { (fó) }\end{array}$ \\
\hline $\begin{array}{l}\text { Az iskolai légkör elfogadó, } \\
\text { gyermekközpontú. }\end{array}$ & 2,81 & 4,15 & 3 \\
\hline A pedagógusok jól tanítanak. & 2,93 & 4,11 & 4 \\
\hline $\begin{array}{l}\text { A pedagógusok szaktárgyi tudása } \\
\text { kiemelkedően jó. }\end{array}$ & 2,89 & 4,34 & 16 \\
\hline $\begin{array}{l}\text { A pedagógusok nyitottak, rugal- } \\
\text { masak, megértőek. }\end{array}$ & 2,85 & 4,15 & 2 \\
\hline A pedagógusok kiváló nevelők. & 2,82 & 4,03 & 10 \\
\hline $\begin{array}{l}\text { A pedagógusok igazságosan } \\
\text { értékelnek. }\end{array}$ & 2,87 & 3,97 & 8 \\
\hline $\begin{array}{l}\text { Színvonalas az idegen nyelvek } \\
\text { oktatása. }\end{array}$ & 2,83 & 4,38 & 11 \\
\hline $\begin{array}{l}\text { A gyerekek jól érzik magukat } \\
\text { az osztályközösségben. }\end{array}$ & 2,90 & 4,41 & 3 \\
\hline Jó a tanár-diák kapcsolat. & 2,90 & 4,25 & 5 \\
\hline $\begin{array}{l}\text { A pedagógusok partnerként kezelik } \\
\text { a szülőket. }\end{array}$ & 2,85 & 4,30 & 4 \\
\hline
\end{tabular}

\subsection{0. táblázat: Szülői elvárások és elégedettség}

A válaszokból kiderül (20. táblázat), hogy a legfontosabb szempontok: a gyerekek jól érezzék magukat az osztályközösségben, jó legyen a tanár-diák kapcsolat, és természetesen a tanárok jól tanítsanak (vö. 5. fejezet). A szülők több mint 80\%-a tartja fontosnak azt, hogy a tanárok igazságosan értékeljenek, rugalmasak, megértőek legyenek. Elvárás a színvonalas idegennyelv-oktatás. A szülőknek igénye van arra is, hogy partnerként kezelje őket a pedagógus.

A szülők a következő szempontokat tették hozzá a kérdőívhez szabad megfogalmazásban: nyolcan azt fogalmazták meg, hogy a másik gyermekük is ide járt, tehát már ismerik 
az iskolát. A következő szempontok 2-3 esetben szerepeltek a leírtak között: a tanító néni személye, információ ismerőstől, közelség a lakóhelyhez vagy a munkahelyhez, színvonalas az iskola, van napközi, illetve tanulószoba, az iskola fenntartója megbízható, van nyelvi előkészítő osztály (ez időközben megszűnt), és szempont volt még a labor léte, a számítógépek, tabletek, interaktív táblák használata.

Arra a kérdésre, hogy miért szeret gyermeke a gyakorlóba járni, 83-an válaszolták, hogy jó az osztályközösség. Szintén nagyszámú válaszadó (78) indokolt azzal, hogy jók a tanárok, tanítók, színvonalas az oktatás. 8-an a tanárokkal való jó kapcsolatot tartották fontosnak, 11-en az osztályfőnök személyét dicsérték. 16 válaszadó a programok sokszínűségét, változatosságát emelte ki, 11 fö az épület könnyü megközelíthetőségét. 7 szülő a sportolási lehetőségekre hívta fel a figyelmet, 6 a jó iskolai légkörre. 4 az emelt szintű nyelvi oktatást tartotta fontosnak. A művészeti nevelés jó minőségét említette 11 szülő. 3 szülő szerint jól cseng az, hogy valaki a gyakorlóiskolába jár, büszkeséggel tölti el a gyereket. 3 szülő említi, hogy a hallgatók néha érdekes órákat tartanak. 1-2 alkalommal szerepel még a következő: van kézilabdázási lehetőség, kórus, barátságos az épület, kulturált a mosdó, és van nyári táborozási lehetőség.

Megvizsgáltuk, hogy az iskolában mennyire jellemző a differenciálás a tanítási-tanulási folyamatban, vagyis a pedagógusok mennyire veszik figyelembe az egyéni sajátosságokat tanítási gyakorlatukban. 


\begin{tabular}{|c|c|c|c|}
\hline kategóriák & $\begin{array}{c}\text { Barkóczy } \\
\text { út } \\
(25 \text { fó) }\end{array}$ & $\begin{array}{l}\text { Bartók } \\
\text { tér } \\
\text { (25 fö) }\end{array}$ & $\begin{array}{c}\text { Mindkét } \\
\text { épület } \\
\text { (14 fö) }\end{array}$ \\
\hline Egyéni fejlesztési terveket készítek. & 3,32 & 3,28 & 3,50 \\
\hline $\begin{array}{l}\text { Személyre szabott követelményeket állítok } \\
\text { tanulóim elé. }\end{array}$ & 3,72 & 4,00 & 3,93 \\
\hline $\begin{array}{l}\text { Minden tanulóval közösen határozom meg } \\
\text { a fejlesztési célokat. }\end{array}$ & 3,12 & 3,48 & 3,57 \\
\hline $\begin{array}{l}\text { A tanórákon, csoportmunka esetén különböző } \\
\text { nehézségű feladatokat adok a diákoknak. }\end{array}$ & 3,88 & 3,96 & 4,00 \\
\hline Egyéni feladatokat adok a tanulóknak az órákon. & 3,56 & 3,64 & 3,86 \\
\hline $\begin{array}{l}\text { Minden diákot a saját képességeihez mérten, } \\
\text { differenciáltan értékelek. }\end{array}$ & 3,76 & 4,04 & 4,36 \\
\hline
\end{tabular}

\subsection{1. táblázat: Az egyéni sajátosságok figyelembevétele a pedagógusok véleménye szerint}

A válaszok alapján elmondható, hogy a differenciálás leginkább az értékelésben jelenik meg, vagyis a pedagógusok közül sokan a diákokat saját képességeikhez mérten értékelik (21. táblázat). Szintén magas átlag szerepel a csoportmunkában történő differenciálásnál és a személyre szabott követelményállításnál.

Megkérdeztük a tanulókat is arról, hogy mennyire érzik a pedagógusok részéről az egyéni sajátosságok figyelembevételét. 


\begin{tabular}{|c|c|c|}
\hline \multicolumn{3}{|c|}{$\begin{array}{l}\text { Kérjük, gondold végig, hogy a gyakorlóiskolai tanórákra ÁLTALÁBAN } \\
\text { mennyire jellemzőek az alábbi állítások! } 1 \text { = egyáltalán nem jellemző, } \\
2 \text { = inkább nem jellemző, } 3 \text { = jellemző is, meg nem is, } 4 \text { = inkább jellemző, } \\
5 \text { = teljes mértékben jellemző }\end{array}$} \\
\hline & $\begin{array}{l}\text { Barkóczy út } \\
\text { (138 fó) }\end{array}$ & $\begin{array}{c}\text { Bartók tér } \\
\text { (117 fó) }\end{array}$ \\
\hline kategóriák & \multicolumn{2}{|c|}{ átlag } \\
\hline A tanárok segítenek, ha problémám van. & 3,53 & 4,08 \\
\hline $\begin{array}{l}\text { Bátorítanak arra, hogy hibázás után is próbáljak } \\
\text { megoldást keresni a feladatokra. }\end{array}$ & 3,55 & 3,58 \\
\hline $\begin{array}{l}\text { Az órákon nincs időnk a feladatokat saját } \\
\text { tempónkban megoldani. }\end{array}$ & 3,11 & 2,91 \\
\hline $\begin{array}{l}\text { A tanárok türelmesek a lassabban haladó } \\
\text { tanulókkal. }\end{array}$ & 2,98 & 3,45 \\
\hline A tanárok segítik a tehetséges gyerekeket. & 3,78 & 4,27 \\
\hline A tanárok segítenek, ha elakadok a tanulásban. & 3,30 & 3,78 \\
\hline
\end{tabular}

\subsection{2. táblázat: Az egyéni sajátosságok figyelembevétele a diákok véleménye szerint}

A tanulók válaszai alapján megállapítható, hogy a pedagógusok a tehetséges tanulókkal és a felzárkóztatásra szorulókkal egyaránt foglalkoznak (22. táblázat). Mindkét tevékenység a Bartók téren van erőteljesebben jelen az átlagok alapján.

Kutattuk, hogy a pedagógusok milyen módszerekkel segítik a lemaradó, lassabban haladó tanulókat, illetve hogyan segítik a tehetséges tanulók fejlődését.

A legtöbben az egyéni foglalkozást írták (38-an). Nagy számban szerepelt a differenciált feladatkiosztás (26), illetve a differenciálás csoportmunkában (13) vagy pármunkában (5). 19-en tartanak felzárkóztató foglalkozást, 36-an egyénileg foglalkoznak a felzárkóztatásra szoruló tanulóval. Személyre szabott feladatokat ad 15 pedagógus, és a motiváció különböző módszereivel próbál jobb eredményt elérni 13 pedagógus. 7 pedagógus sorolta fel a kooperatív technikák alkalmazását, 6 a szemléltetést. Érdekes, hogy igen elenyésző számban iktatnak be több gyakorlóórát (2), vagy adnak tanulásmódszertani segítséget (mindössze 1 fó). 2 pedagógus ír egyéni fejlesztési tervet, és 3 a szülőkkel való együttműködés segítségével végzi az egyéni fejlesztést. 4 fó a pozitív értékelés segítségével motiválja a tanulókat. 1 pedagógus a követelményt egyénekre szabja, és ennek megfelelően értékel. 
Kiemelkedő a versenyekre való felkészítés, versenyeztetés, amit 35-en szerepeltettek. A tanulókkal való egyéni foglalkozást 28 fö jelölte. A differenciált feladatkiosztás 27-szer, a differenciálás csoportmunkában 7-szer szerepel. Az önálló ismeretszerzést 11-en segítik, egyénre szabott feladatokat 10-en adnak a tanulóknak. A szakkört 11 pedagógus említi, a felfedeztetve tanítást, kutatómunkát 8 fö. Kooperatív technikákat 8 -an alkalmaznak a tehetséggondozásnál. 11 pedagógus tanulói kiselőadásokat, prezentációkat nevezett meg tehetségfejlesztő módszerként. Kisebb számban jelenik meg a válaszok közt a szemléltetés (3), ami nem tehetséggondozó módszer, a szakirodalom-ajánlás (1), a táboroztatás (1), a laborgyakorlat (2), az egyéni fejlesztési terv írása (1), a motiváció (5), a vitaszervezés (2), a projektmódszer (6), az iskolán kívüli tapasztalatszerzés irányítása (1), a kritikus gondolkodás fejlesztése (2), a problémamegoldó gondolkodás fejlesztése (2), az élménypedagógia módszerei (1), a múzeumpedagógia (2) és az irányítás tehetséggondozó központok, foglalkozások felé.

Arra a kérdésre, hogy gyermeke melyik tárgyból fejlődött a legjobban, a legtöbb szülő a matematikát nevezte meg (58), másodikként az angol nyelv szerepel (52). 15-en a magyart, 6 -an az irodalmat, 7-en a nyelvtant jelölték. A történelmet 13, a kémiát 8 , a természetismeretet 7 , a németet 7 , a környezetismeretet 6 szülő szerepeltette. Az alsó tagozatos írás 7, az olvasás 8, az írás 1 alkalommal szerepel. Viszonylag kis számban említik a szülők a testnevelést (5), a földrajzot (4), a biológiát (4), a fizikát (3), az informatikát (3), az éneket (2), a rajzot (5) és a franciát. 8 válaszoló szerint mindenből fejlődött gyermeke, míg 9 szerint semmiből sem. 4-en nem tudják.

Arról kérdeztük a szülőket, mi az oka gyermekük fejlődésének.

\begin{tabular}{|l|c|c|c|c|}
\hline & \multicolumn{2}{|c|}{ választotta } & \multicolumn{2}{c|}{ nem választotta } \\
\hline kategóriák & gyakoriság & $\begin{array}{l}\text { százalékos } \\
\text { gyakoriság }\end{array}$ & gyakoriság & $\begin{array}{l}\text { százalékos } \\
\text { gyakoriság }\end{array}$ \\
\hline $\begin{array}{l}\text { Gyermekem szorgalmasabb } \\
\text { volt, mint korábban. }\end{array}$ & 73 & 29,6 & 174 & 70,4 \\
\hline $\begin{array}{l}\text { Jobb módszerekkel tanított } \\
\text { az adott pedagógus. }\end{array}$ & 65 & 26,3 & 182 & 73,7 \\
\hline $\begin{array}{l}\text { Gyermekemet jobban érde- } \\
\text { kelte az adott tantárgy, mint } \\
\text { korábban. }\end{array}$ & 87 & 35,2 & 160 & 64,8 \\
\hline $\begin{array}{l}\text { Nagyon jó kapcsolat alakult } \\
\text { ki gyermekem és az adott } \\
\text { tantárgyat tanító pedagógus } \\
\text { között. }\end{array}$ & $\mathbf{1 2 0}$ & $\mathbf{4 8 , 6}$ & 127 & 51,4 \\
\hline
\end{tabular}

6.23. táblázat: A szülők véleménye a gyermekük fejlődéséről 
Az előző kérdéseknél már láttuk, hogy a szülők fontosnak tartják a tanár-diák jó kapcsolatát, és ebben a kérdésben is ezt erősítik meg, hiszen legtöbben (48,6\%) ennek tulajdonítják gyermekük fejlődését (23. táblázat). Ezen kívül „a gyermeket jobban érdekelte a tantárgy és a szorgalmasabb volt, mint korábban” választ jelölték be a szülők. Csak negyedik helyen szerepel a rangsorban a jobb módszerek alkalmazása.

A szülők gyermekük fejlődése okaként a következőket sorolták fel egyéb kategóriaként: 4-en a motiváltságot, 3-an az otthoni gyakorlást, 3-an a tanárváltásnak tulajdonítják a fejlődést. 1 szülő gyermeke szorgalmát nevezte meg, szintén 1 a versenyeztetést írta, míg 5 szerint gyermeke nem fejlődött. 3-an nem tudják az okot.

Kíváncsiak voltunk arra, hogy a szülők véleménye szerint a tanárok hogyan segítik a tanulókat a jobb eredmények elérése érdekében. A legnagyobb számban szövegesen a felzárkóztató foglalkozást említették (18-an), illetve azt, hogy gyermeküket motiválja a pedagógus (11-en). 10 fó a versenyeket nevezte meg, szintén 10 azt írta, hogy a pedagógusok a szülőknek jeleznek, ha a gyermek lemarad. 7 szülö szerint a pedagógusok nem segítenek sehogy, 7 szerint a gyerek több feladatot kap gyakorlásnak. 6 fó a tehetséggondozást nevezte meg, szintén hatan a tanórai többletgyakorlást írták. Kisebb számban (2-3 alkalommal) szerepelt az, hogy van, aki az érdekes tanóráival, dicsérettel, önbizalom-növeléssel, magas követelményekkel, tanulási tanácsokkal, könyvekkel, javító dolgozatok írásával, megfelelő értékeléssel, differenciált órai munkával, több magyarázattal segít a tanulóknak. 7 fö szerint a pedagógusok nem segítenek, másik 7 fó nem tudja.

A szülők válaszai azt tükrözik, hogy nincs tudomásuk a pedagógusok széles körü differenciáló munkájáról, vagy a pedagógusok nem voltak őszinték.

Az alsós tanulók válaszai:

\begin{tabular}{l}
\hline $\begin{array}{l}\text { Ha az iskolai tanórákra gondolsz, szerinted általában mennyire jellemzóek } \\
\text { az alábbi állítások? }\end{array}$ \\
\hline $\mathbf{N}=\mathbf{7 9}$ \\
\hline
\end{tabular}

6.24. táblázat: Alsós tanulók véleménye a tanulás segítéséről 
Felsős tanulói válaszok:

\begin{tabular}{|c|c|c|c|c|c|}
\hline \multicolumn{6}{|c|}{ Szerinted mennyire jellemzőek az alábbi tulajdonságok az iskolára? } \\
\hline \multirow{2}{*}{$\begin{array}{l}\mathrm{N}=255 \\
\text { kategóriák }\end{array}$} & \multicolumn{5}{|c|}{ százalékos gyakoriság (\%) } \\
\hline & 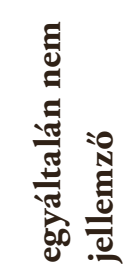 & 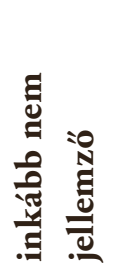 & 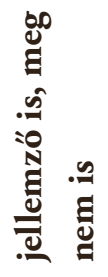 & 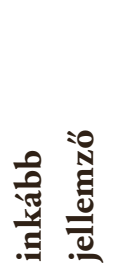 & 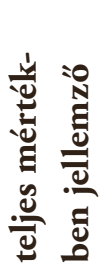 \\
\hline $\begin{array}{l}\text { A tanárok segítenek, ha } \\
\text { problémám van. }\end{array}$ & 3,5 & 6,7 & 28,2 & 31,4 & 30,2 \\
\hline $\begin{array}{l}\text { A tanárok türelmesek a lassabban } \\
\text { haladó tanulókkal. }\end{array}$ & 8,6 & 13,3 & 38,0 & 29,8 & 10,2 \\
\hline $\begin{array}{l}\text { A tanárok segítik a tehetséges } \\
\text { gyerekeket. }\end{array}$ & 1,6 & 4,3 & 22,4 & 36,5 & 35,3 \\
\hline $\begin{array}{l}\text { Bátorítanak arra, hogy hibázás } \\
\text { után is próbáljak megoldást } \\
\text { keresni a feladatokra. }\end{array}$ & 4,7 & 6,7 & 25,9 & 34,1 & 28,6 \\
\hline $\begin{array}{l}\text { A tanárok segítenek, ha elakadok } \\
\text { a tanulásban. }\end{array}$ & 7,1 & 9,4 & 31,0 & 30,2 & 22,4 \\
\hline $\begin{array}{l}\text { Az órákon nincs időnk } \\
\text { a feladatokat saját tempónkban } \\
\text { megoldani. }\end{array}$ & 9,0 & 21,2 & 42,0 & 14,5 & 13,3 \\
\hline
\end{tabular}

\subsection{5. táblázat: Felsős tanulók véleménye a tanulás támogatásáról}

A tanulói válaszokból az derül ki, hogy a tanulók jelentős százaléka úgy érzi, kap segítséget a tanáraitól, de oda kell figyelni arra a 40\%-ra, aki viszont ezt nem így tapasztalja (24. táblázat). Lehet, hogy ők a lemaradó, lassabban haladó diákok? A felsős diákok több mint 60\%-a úgy gondolja, hogy a tehetséges tanulókat is segítik a tanárok (25. táblázat). 


\section{Az iskola felszereltsége}

Megkérdeztük a pedagógusok és a szülők véleményét, hogy az iskola infrastruktúrája, az épület, a berendezés, az eszközök állapota mennyire alkalmas a feladatok teljesítésére. Alkalmas-e a tanulási környezet arra, hogy segítse a mindennapi tevékenységet, a tanulást és a hallgatók képzését? Megvannak-e a modern digitális pedagógia eszközei? A kooperatív munka, a korszerü módszerek flexibilis megoldásokat és teret igényelnek. Ezeket a módszereket nehéz alkalmazni a hagyományos termekben. A mozgáshoz, játékhoz, csoportmunkához rögzített padok helyett átrendezhető tantermi bútorzat szükséges.

A pedagógusok 58,4\%-a úgy gondolja, hogy a jó felszereltség segíti az iskola eredményességét.

A szülők véleményére is kíváncsiak voltunk ezen a területen is.

\begin{tabular}{|c|c|c|c|c|}
\hline \multicolumn{5}{|c|}{$\begin{array}{l}\text { Ön szerint milyen mértékben akadályozzák vagy segítik az alábbi tényezők } \\
\text { az iskola színvonalának emelkedését? }\end{array}$} \\
\hline $\mathbf{N}=247$ & $\begin{array}{c}\text { a tanórákhoz } \\
\text { szükséges } \\
\text { eszközök }\end{array}$ & $\begin{array}{l}\text { a tantermek } \\
\text { berendezése }\end{array}$ & $\begin{array}{c}\text { az } \\
\text { órarend }\end{array}$ & $\begin{array}{c}\text { az iskola } \\
\text { infrastruk- } \\
\text { túrája }\end{array}$ \\
\hline $\begin{array}{l}\text { nagymértékben } \\
\text { akadályozza }\end{array}$ & 4 & 5 & 13 & 4 \\
\hline $\begin{array}{l}\text { inkább } \\
\text { akadályozza }\end{array}$ & & 6 & 14 & 4 \\
\hline $\begin{array}{l}\text { részben akadá- } \\
\text { lyozza, részben } \\
\text { segíti }\end{array}$ & 10 & 18 & 56 & 11 \\
\hline inkább segíti & 68 & 96 & 68 & 83 \\
\hline $\begin{array}{l}\text { nagymértékben } \\
\text { segíti }\end{array}$ & 154 & 101 & 75 & 121 \\
\hline nem befolyásolja & 5 & 14 & 8 & 5 \\
\hline $\begin{array}{l}\text { nem tudom } \\
\text { megítélni }\end{array}$ & 6 & 7 & 13 & 19 \\
\hline
\end{tabular}

6.26. táblázat: Milyen mértékben akadályozzák vagy segítik az alábbi tényezők az iskola színvonalának emelkedését? 
A megkérdezett szülők is úgy gondolják, hogy az iskola felszereltsége, infrastruktúrája nagymértékben segíti az iskola színvonalának emelkedését. Többen viszont (28fó) az udvar rendbehozatalát hiányolják (26. táblázat). Ez valószínű, hogy a Bartók téri udvarra vonatkozik, mert portalanításról és sártalanításról tesznek említést.

A szülők fontosnak tartják az épületek és a tantermek korszerüsítését, említik a padok rossz állapotát, a polcok, szekrények, függönyök hiányát, az elromlott projektorok javításának elmaradását.

Külön területenként megvizsgáltuk, hogy milyennek vélik a pedagógusok az általuk használt eszközök állapotát.

Véleménye szerint milyen az Ön által használt eszközök állapota? Kérjük, válaszát a megfelelő szám megadásával jelölje! [ „1 = kiemelkedően rossz”, „2 = inkább rossz”, „3 = közepes”, „4 = inkább jó”, „5 = kiemelkedően jó”, „9 = nem tudom megítélni”]

\begin{tabular}{|l|c|c|}
\hline $\mathbf{N}=\mathbf{1 2 5}$ & átlag & $\begin{array}{c}\text { Hány fó } \\
\text { nem tudja } \\
\text { megítélni? }\end{array}$ \\
\hline informatikai eszközök & 3,61 & 5 \\
\hline idegennyelvi oktatáshoz szükséges eszközök & 3,43 & 71 \\
\hline humán tantárgyak oktatásához szükséges eszközök & 3,72 & 47 \\
\hline $\begin{array}{l}\text { a természettudományos tantárgyak oktatásához } \\
\text { szükséges eszközök }\end{array}$ & $\mathbf{4 , 4 6}$ & $\mathbf{3 4}$ \\
\hline testnevelés oktatásához szükséges eszközök & 2,89 & 44 \\
\hline $\begin{array}{l}\text { mindennapos testnevelés oktatásához szülsséges } \\
\text { eszközök }\end{array}$ & $\mathbf{2 , 5}$ & $\mathbf{4 1}$ \\
\hline müvészeti neveléshez szükséges eszközök & 3,5 & 61 \\
\hline könyvtári felszereltség & 3,64 & 11 \\
\hline
\end{tabular}

\subsection{7. táblázat: Milyen az Ön által használt eszközök állapota?}

A természettudományos tárgyak oktatásához biztosítottak az eszközök, hiszen mindkét épület rendelkezik egy-egy korszerü laboratóriummal. A testnevelés oktatásához viszont nincsenek meg a megfelelő eszközök (27. táblázat).

A vezetőtanárokat a gyakorlótanításhoz szükséges tárgyi feltételekről külön is megkérdeztük. A válaszadó pedagógusok 73\%-a elégedett a rendelkezésre álló felszereléssel, feltételekkel. 
Akik elégedetlenek a tárgyi feltételekkel, több digitális táblát szeretnének, a hallgatói megbeszéléshez megfelelő helyet, illetve a zsúfolt tornatermet kifogásolták és a sportszerek hiányát.

A tanárjelöltekkel folytatott megbeszélések helyszíneire külön is rákérdeztünk.

\begin{tabular}{|l|c|c|l|}
\hline $\begin{array}{l}\text { Ön leggyakrabban hol szokta megvalósítani a gyakorlaton } \\
\text { lévö tanárjelöltekkel folytatott megbeszéléseit? Kérjük, } \\
\text { válassza ki az alábbi listából azokat a helyszíneket, amelyeket } \\
\text { a leggyakrabban szokott használni! }\end{array}$ & $\begin{array}{l}\text { Véleménye } \\
\text { szerint mennyire } \\
\text { megfelelőek ezek } \\
\text { a helyszínek } \\
\text { a tanárjelöltekkel } \\
\text { folytatott } \\
\text { megbeszélésekhez? }\end{array}$ \\
\hline Megbeszélöszoba & 9 & 93 & 4,6 \\
\hline Tanári & 13 & 89 & 2,3 \\
\hline Tanterem & 15 & 87 & 3,6 \\
\hline Büfé & 4 & 98 & 1,4 \\
\hline Étterem & 1 & 101 & 1,2 \\
\hline Könyvtár & 7 & 95 & 3,8 \\
\hline Szertár & 8 & 94 & 3,3 \\
\hline Folyosó & $\mathbf{2 6}$ & 76 & 2,4 \\
\hline
\end{tabular}

\subsection{8. táblázat: A tanárjelöltekkel folytatott megbeszélések helyszínei}

A táblázatból látható, hogy a folyosón és a tanáriban történik a megbeszélések nagy része (28. táblázat). Jól látható, hogy nem megfelelőek a rendelkezésre álló helyszínek a hallgatókkal való munkához. A gyakorlóiskolában a vezetőtanárok tekintélyes része a folyosón tartja az óramegbeszéléseket.

\section{Hipotéziseink igazolása}

H1: A gyakorlóiskola tanárainak többsége hatékonyan irányítja a tanítás-tanulás folyamatát. A szülők és a kompetenciafelmérés adataiból az derül ki, hogy a gyakorlóiskola tanárainak többsége hatékonyan irányítja a tanítás-tanulás folyamatát. Ez azonban nem azt jelenti, hogy ennél eredményesebb munkával ne lehetne javítani a hozzáadott értéken. 
H2: A szülők az iskolaválasztásnál a gyakorlóiskolában folyó szakmai munka minőségét veszik elsősorban figyelembe.

A feltételezés beigazolódott. A szülők nagy része számára a legfontosabb az iskolaválasztásnál, hogy a tanárok jól tanítsanak. Fontos szempont még, hogy a gyerekek jól érezzék magukat az osztályközösségben, és jó legyen a tanár-diák kapcsolat.

H3: A szülők többsége elégedett a gyakorlóiskola pedagógusainak tevékenységével.

Ez a feltételezés csak részben igazolódott be. Amíg ugyanis sokan teljesen elégedettek azzal, ahogyan a pedagógusok tanítanak, a tanár-diák kapcsolattal, a pedagógusok nevelési tevékenységével vagy szaktárgyi tudásával, nagyszámú válaszadó semleges választ adott erre a kérdésre. Igen kis számban bizonyultak azonban egyáltalán nem elégedettnek.

H4: A pedagógusok önreflektíven elemzik saját tevékenységüket, ezzel is példát mutatva a tanárjelölteknek.

Ez a feltételezés részben beigazolódott. A pedagógusok válaszaik szerint önreflektíven gondolják át saját tanítási gyakorlatukat.

H5: A pedagógusokban nagy igény van a szakmai fejlődésre.

Ez a hipotézis részben igazolódott. A pedagógusok közel egyharmada nem követi a szakirodalmat, és a tudásmegosztásra irányuló tevékenységek jelenléte nem gyakori az intézményben.

H6: A pedagógusok motiváltak arra, hogy tudásukat megosszák kollégáikkal.

Ez a feltételezés nem igazolódott be. Az egymástól való tanulást nem segíti elö, hogy a tudásmegosztást elősegítő szakmai programok, a bemutatóórák, műhelyek tartásának szándéka csak kismértékben mutatkozik meg.

H7: Az egyetem és a gyakorlóiskola közötti szakmai együttműködés nem erős.

Ez a feltételezés beigazolódott. A pedagógusok többsége nem érzi fontosnak az egyetemmel való együttműködést. Pedig fontos lenne az együttműködés, hiszen a hallgatók képzése érdekében szükség lenne szélesebb körủ egyeztetésre és az egyetem tudásbázisának nagyobb fokú kihasználására. Elképzelhető lenne olyan együttmüködés is, amelyben az egyetem segít a gyakorlóiskolának humánerőforrás-hiány esetén tehetséges hallgatókkal. 


\section{3. Összegzés}

Kutatásunk során az Eszterházy Károly Egyetem gyakorlóiskolájának színvonalát, eredményességét, vonzerejét vizsgáltuk. Célunk egyfajta diagnózis felállitása volt annak érdekében, hogy a szakmai fejlesztő iskola mint fejlesztési cél szempontjából milyen lépéseket szükséges megtenni a jövőben. Megkérdeztük a pedagógusok, szülők, diákok véleményét, valamint az egyetem hallgatóit. A kérdőívekre adott válaszok alapján az alábbi eredményekre jutottunk:

- A szülők elvárásai a gyakorlóiskolával szemben

A szülők legfontosabb elvárásai az iskolakezdés előtt, hogy a tanárok jól tanítsanak, a gyerekek jól érezzék magukat az osztályközösségben, és jó legyen a tanár-diák kapcsolat. Elvárás a színvonalas idegen nyelvoktatás. Azt vizsgálva, hogy ezek az elvárások mennyire teljesültek, elmondhatjuk, hogy a szülők nagy része elégedettségét fogalmazta meg a felsorolt tényezők tekintetében.

- Az iskola vezetése

Az iskolavezetés munkájára vonatkozó kérdésekre a pedagógusok 60\%-a semleges választ adott, tehát nem foglalt állást, míg az iskola eredményességét befolyásoló tényezők közt a többség nem jelölte a vezetés színvonalas munkáját. Ezzel összefüggésben megjegyzendő, hogy többen kifogásolták a beazonosíthatóságot a kitöltésnél.

- Az iskola eredményességét befolyásoló tényezők Fontosnak tartottuk annak tisztázását, hogy a pedagógusok mely pedagógiai célokat tűzik ki leginkább munkájuk során. Az adatok alapján kiderült, hogy a pedagógusok többsége a gondolkodás fejlesztését és a tanulók aktív tevékenységét látja legfontosabb célnak.

A pedagógusok jellemezték saját tevékenységüket. A többség saját szaktudását kiválónak tartja, a szakirodalmat viszont ezen válaszolóknak csak egy része követi, és tudásmegosztásra sem hajlandó minden önmagát kiváló szaktudásúnak ítélő. Az önreflektív szemlélet a válaszolók többségénél jelen van saját bevallása szerint. Érdekes viszont, hogy közel egyharmaduk nem mindig készül óravázlattal.

A válaszadó pedagógusok és szülők szerint a pedagógusok motiváltsága és szakmai felkészültsége segíti leginkább az iskola eredményességét. A tudásmegosztást ennél a kérdésnél is kevesen jelölték fontosnak, jóval nagyobb arányban említik a jó felszereltség fontosságát. Az egyetemmel való együttműködést a pedagógusok nagy része nem érzi lényegesnek a nagyobb eredményesség érdekében.

A színvonalas tehetséggondozást viszonylag kevesen gondolják az iskola eredményességét pozitívan befolyásoló tényezőnek.

A pedagógusok motiváltsága és jó felkészültsége, magas szintủ szakmai tudása nagy mértékben befolyásolja az iskola eredményességét mind a pedagógusok, mind a szülők 
véleménye szerint. A szülők véleménye természetesen megosztottabb ezekben a kérdésekben. A jó felszereltség és infrastruktúra is a befolyásoló tényezők között szerepel.

- Az iskola eredményességét akadályozó tényezők

A pedagógusok és a szülök is úgy vélekednek, hogy a pedagógusok túlterheltsége a legnagyobb akadályozó tényezője az iskola fejlődésének.

Fejlődést gátló tényező a tanulók felkészületlensége is, de ebben a pedagógusok felelősségét is meg kell vizsgálni.

- Infrastruktúra és szervezési feltételek

A gyakorlóiskola felszereltsége néhány területen kiemelkedő (természettudományos labor, projektorok), viszont vannak elhanyagolt területek (nyelvoktatás, informatika), ahol hiányoznak az eredményes munkához szükséges eszközök.

Sok szülő kifogásolja a Bartók téri udvar állapotát és a menza korszerüsítését. Sokan említik, hogy az órarend sok lyukasórát tartalmaz, és a tanítási nap a délutánba nyúlik. Igen nagy számban kifogásolják a szülők a menzai étkezés minőségét.

- Differenciálás, felzárkóztatás, tehetséggondozás

A gyakorlóiskolában a pedagógusok válaszai szerint figyelembe veszik a tanulók egyéni képességeit, segítik a tanulókat, ha lemaradnak, illetve a tehetséges tanulók fejlődése, kibontakozása is biztosított. Ez a törekvés a pedagógiai célok vizsgálatakor egyértelmüen kirajzolódott, hiszen a többség fontosnak tartja az egyéni tanulási képességekhez, adottságokhoz való alkalmazkodást. Amikor azonban az iskola eredményességét befolyásoló tényezőket vették számba, viszonylag kevesen jelölték a színvonalas tehetséggondozást. A pedagógusok sokféle tevékenységet megneveztek a tehetséggondozás és felzárkóztatás területén. Ezekből a felsorolásokból azonban nem lehet következtetni ezen tevékenységek eredményességi fokára.

\section{Javaslatok}

Javaslatok az iskola vezetőségének:

- Nagyobb mértékben vonja be a pedagógusokat a szakmai döntésekbe, gondolja át az alulról jövő kritikákat, és alakítson ki demokratikusabb légkört+

Javaslatok a fenntartónak, vezetőségnek és pedagógusoknak:

- Szorosabbá kellene tenni az egyetem oktatói és a gyakorlóiskolában dolgozó pedagógusok együttműködését a hallgatók összehangoltabb és hatékonyabb felkészítése érdekében.

- Az infrastruktúrán, iskolai felszereltségen még lehet javítani, fejleszteni, így olyan pályázatok írására lenne szükség, melyekben az eszközök fejlesztésére van lehetőség. 
- Szükséges az iskola mindkét épületében egy-egy megbeszélőszoba, ahol a vezetőtanárok és a hallgatók nyugodt körülmények között tudják a megbeszéléseiket folytatni.

- Egy szakmai fejlesztő iskola feladatköre jóval nagyobb, mint egy átlagos köznevelési intézményé. Ahhoz, hogy a gyakorlóiskola szakmai fejlesztő iskolává váljon, és a pedagógusok aktívabban vegyenek részt kutatómunkában, szakmai műhelyek tartásában melyek nagyon időigényes tevékenységek -, tehermentesíteni kell őket olyan feladatok alól, amelyeket a pedagógiai asszisztensek is el tudnak végezni. Szükség lenne tehát bizonyos személyzeti fejlesztésekre.

Javaslatok az iskola vezetőségének és a pedagógusoknak:

- A kommunikáció javítása, hiszen a szülőknek kevés információja van az iskolában folyó munkáról.

- Az egyetemmel való szorosabb együttműködésre való törekvés új tanárok alkalmazásánál, nagyobb támaszkodás az egyetem ez irányú ajánlásaira, javaslataira.

- Az egyenletes munkaterhelés megvalósítása a tantestületben.

Javaslatok a pedagógusoknak:

- Az iskolájukban végzett magas színvonalú munkát, jó gyakorlatokat, kipróbált módszereket mutassák be műhelymunka, illetve továbbképzések során! Vállaljanak bemutatóórákat saját kollégáik előtt és más iskolákban tanító kollégák előtt is!

- A szöveges válaszokból kiderül, hogy mindössze 1 pedagógus ad tanulásmódszertani segítséget a lemaradóknak. Javasoljuk, hogy ezt a segítséget minden pedagógus adja meg a tanulási gondokkal küzdőknek.

- A szakmai fejlődés érdekében elengedhetetlen a szakirodalom nyomon követése.

- A magas színvonalú tanórák megtartásához fontos a minden órára való tervezés.

\section{Felhasznált irodalom:}

Coleman, J. S. (1966): Equality of educational opportunity. Washington, DC. US Government Printing Office, 749.

Darling-Hammond, L. (2000): Teacher Quality and Student Achievement. A review of State Policy Evidence. Education Policy Analysis Archives, vol. 8. No. 1. pp. 1-46 https://doi.org/10.14507/epaa.v8n1.2000

Epstein, L. J (2001): Partnering with families and communities http://mnliteracy.org/sites/ default/files/partnering_with_families_and_communities_-_epstein.pdf 
Fullan, M. (2010): All Systems go. The Change Imperative for Whole System Reform. Thousand Oaks. California. Corwin Press.

Goldhaber, D. (2002): The Mystery of Good Teaching. Surveying the Evidence on Student Achievement and Teacher Characteristics. Education Next, 2 (1), pp. 50-55.

Goldthorpe, J. és Erikson, R. (2002): Intergenerational Inequality. A Sociological Perspective. Journal of Economic Perspectives, 16. https://doi.org/10.1257/089533002760278695

Gyökös Eleonóra (2015): Az iskolák teljesitményének nyomában - az eredményességtöl a hozzáadott értékig. In: Szemerszki Marianna (szerk.): Eredményesség az oktatásban. Dimenziók és megközelítések. Budapest. Oktatáskutató és Fejlesztő Intézet.

Hanushek, E. A. (1992): The Trade-off Between Child Quantity and Quality. Journal of Political Economy 100 (1), pp. 84-117. https://doi.org/10.1086/261808

Hargreaves, A. és Fullan, M. (2012): Professional Capital: Transforming teaching in every school. New York and London, Teachers College Press.

Hattie, J. A. C. (2009): Visible Learning: A synthesis of over 800 meta-analyses relating to achievement. London, Routledge.

Hopkins, D. (1991): School improvement for real.

http://fszk.hu/images/stories/4_Hopkins-differential_BM.pdf

Leithwood, K. A. és Riehl, C. (2003): What we know about successful school leadership. Philadelphia, PA: Laboratory for Student Success, Temple University.

Scheerens, J., Glas, C. és Thomas, S. M. (2003): Educational Evaluation, Assessment and Monitoring. A Systematic Approach. Lisse, Swets \& Zeitlinger Publishers.

Teddlie,C. és Reynolds, D.(2000): The international handbook of school effectiveness research. New York. Falmer Press, 397. 